\title{
Sanal Kaytarma ve İşgören Performansı İlişkisinde İş Stresinin Düzenleyici Etkisinin İncelenmesi: Sağlık Sektöründe Bir Araştırma*
}

\author{
Investigation of The Moderator Effect of Job Stress on The Relationship Between \\ Cyberloafing and Employee Performance: A Research on Health Sector
}

\author{
Doktora Öğrencisi Mesut ÖZÜDOĞRU(i)1, Doç. Dr. Yavuz Tansoy YILDIRIM(D22
}

\begin{abstract}
$\ddot{\mathbf{O} z}$
$\mathrm{Bu}$ araştırmanın amacı iş stresinin, sanal kaytarma ve işgören performansı ilişkisi üzerinde anlamlı bir etkisinin olup olmadığını belirlemektir. Bu amacı gerçekleştirmek için "Sanal Kaytarma", "İşgören Performansı" ve "İ̧̧ Stresi Ölçekleri" Balıkesir ilinde kamuda görevli 402 sağlık çalışanına uygulanmıştır. Toplanan veriler üzerinde frekans analizi, faktör analizi, güvenilirlik analizi, normallik testi, korelasyon analizi ve regresyon analizi testleri uygulanmıştır. Korelasyon analizi sonucuna göre sanal kaytarma, işgören performansı ve iş stresi arasında anlamlı ilişkilerin olduğu tespit edilmiştir. Regresyon analizi sonucunda iş stresinin, sanal kaytarma ve işgören performansı ilişkisi üzerinde düzenleyici etkisinin olduğu tespit edilmiştir. Yöneticiler ve yapılacak araştırmalar için önerilerde bulunulmuştur. Araştırmanın bulgularının literatüre ve uygulayıcılara katkı sağlayacağı düşünülmektedir.
\end{abstract}

Anahtar Kelimeler: Sanal kaytarma, sanal aylaklık, işgören performansı, çalı̧̧an performansı, iş stresi

Makale Türü: Araştırma

\begin{abstract}
The aim of this study is to determine whether job stress has a significant effect on the relationship between cyberloafing and employee performance. With this aim, "Cyberloafing", "Employee Performance" and "Job Stress" scales were applied 402 public health employees in Balıkesir. Frequency analysis, factor analysis, reliability analysis, test for normality, correlation analysis, and regression analysis were applied on the collected data. According to the correlation analysis, it was found that there were significant relationships between cyberloafing, employee performance and job stress. As a result of the regression analysis, it was found that job stress has a moderator effect on the relationship between cyberloafing and employee performance. Managerial and further research implications are provided. It is thought that the findings of this study can contribute to both literature and applicators.
\end{abstract}

Keywords: Cyberloafing, cyberslacking, employee performance, worker performance, job stress

Paper Type: Research

\footnotetext{
*Bu çalışma, "Sanal Kaytarma ve İşgören Performansı İlişkisinde İş Stresinin Düzenleyici Etkisinin İncelenmesi: Sağlık Sektöründe Bir Araştırma" adlı yüksek lisans tez çalışmasından üretilmiştir.

${ }^{1}$ Çanakkale Onsekiz Mart Üniversitesi, Biga İktisadi ve İdari Bilimler Fakültesi, mesutozudogru@yahoo.com.

${ }^{2}$ Bandırma Onyedi Eylül Üniversitesi, Bandırma MYO, ytyildirim@bandirma.edu.tr.
}

Atıf için (to cite): Özüdoğru, M., Yıldırım, YT. (2020). Sanal kaytarma ve işgören performansı ilişkisinde iş stresinin düzenleyici etkisinin incelenmesi: sağlık sektöründe bir araştırma. Afyon Kocatepe Üniversitesi Sosyal Bilimler Dergisi, 22(2), 467-490. 


\section{Giriş}

Örgütlerin belirlediği amaçlara ulaşabilmesindeki en önemli unsurlardan birisi işgörenlerin performansıdır. Örgütlerin başarısı ya da başarısızlığı işgörenlerin performansına bağlı olduğu için, performans üzerinde olumlu ya da olumsuz etkisi bulunan unsurların belirlenmesi hayati önem arz etmektedir. Çalışanların sanal kaytarma davranışları ve iş stresi, performanslarını etkileyen unsurlardan bazıları olarak karşımıza çıkmaktadır.

Bilişim teknolojilerinin hızlı gelişimi ve örgütler üzerindeki etkisinin artmasıyla birlikte ortaya çıkan sanal kaytarma kavramı, son yıllarda araştırmacıların dikkatini çeken bir konu haline gelmiştir. TÜIKK tarafından yapılan araştırmaya göre, 10 ve daha fazla çalışanı bulunan işletmelerin internet erişim oranı \%95,3 olarak tespit edilmiştir (TÜİK, 2018a). Bu orandan anlaşılacağı üzere, işletmelerin neredeyse hepsi, faaliyetlerini gerçekleştirebilmek için internet erişimine ihtiyaç duymaktadır. İşletmelerin yanında bireylerin de internet kullanımı, akıllı telefonların da etkisiyle son yıllarda artmıştır. TÜİK verilerine göre, 2005 yılında bireylerin internet kullanım oran $\% 27,8$ iken, 2018 y1lında ise \%90,7 olarak tespit edilmiştir (TÜIK, 2018b). Bilişim teknolojilerinin yaygın olarak kullanımı işletmelere birçok fayda sağlamakla birlikte, çalışanlar tarafından internet erişimi, mesai saatleri içerisinde kişisel amaçlar için kullanılarak, çalışma zamanı suistimal edilebilmektedir. $\mathrm{Bu}$ davranış literatürde araştırmacılar tarafından sanal kaytarma olarak tanımlanmıştır. ABD'de yapılan bir araştırmaya göre 34 milyon çalışanın haftada 200,6 milyon saat sanal kaytarma yaptığı tespit edilmiştir. Sanal kaytarma, çalışanlar tarafindan iş yerindeki internetin kişisel amaçlar için, iş dış1 kullanılması olarak tanımlanmaktadır (Blanchard ve Henle, 2008, s. 1068).

İşgörenlerin sanal kaytarma davranışları ile performansları arasındaki ilişki konusunda yapılan çalışmalarda farklı sonuçların elde edildiği görülmektedir. Bazı çalışmalarda bu davranışların çalışanlar üzerinde yenilenme etkisi bulunduğu ve bu etki ile çalışanların işe daha iyi odaklandıkları belirtilmiştir. Ancak bu görüşün aksine bazı araştırmalarda ise bu davranışların işgörenlerin performansı üzerinde olumsuz etkiye sahip olduğu tespit edilmiştir.

İsgörenlerin performansını etkileyen bir diğer unsur da çağımızın en büyük problemlerinden biri olarak görülen strestir. Her mesleğin ya da işin doğasında bulunan stres, belli bir seviyeye kadar çalışanların performansını olumlu yönde etkilerken, aşırı düzeylerde ise olumsuz yönde etkilemektedir (Kyriacou, 200, s. 33). Araştırmanın örneklemini oluş̧uran sağlık sektörü çalışanlarının yoğun stres altında çalıştığı belirtilmekte ve uyarıcılara karşı farklı tepki verdikleri belirtilmektedir (Şahin ve Batıgün, 1997, s. 62, Kıyat, Özgüleş ve Günaydın, 2018, s. 474). Sağlık personelinin sanal kaytarma davranışlarının performansları üzerindeki etkisinde iş stresinin düzenleyici etkisi olduğu öngörülmektedir. Çalışmanın, sanal kaytarma ve işgören performansı ilişkisinde iş stresinin düzenleyici etkisini araştıran ilk çalışma olması nedeniyle literatüre önemli katkısı olacağı düşünülmektedir.

\section{Kavramsal Çerçeve}

\subsection{Sanal Kaytarma}

Literatüre bakıldığında yazım dili İngilizce olan çalışmalarda sanal kaytarma kavramı, "cyberslacking", "cyberloafing", "cyber deviance", "cyberdeviancy", "personal web usage" ve "cyberbludging", yazım dili Türkçe olan çalışmalarda ise, "sanal kaytarma", yanı sıra "sanal aylaklık", "sanal tembellik", "siber kaytarma", ve "siber aylaklık" olarak kullanılmaktadır. Literatürü incelediğimizde, sanal kaytarma kavramı ile ilgili olarak, araştırmacılar tarafından çeşitli tanımlamalar yapılmıştır. Bu tanımlamalardan bazıları aşağıda belirtilmiştir.

Sanal kaytarma, çalışanların istemli bir şekilde, şirketlerinin internetini kullanarak, mesai saatlerinde kişisel amaçlar için, işle ilgisi olmayan web sitelerini ziyaret etmesi, kişisel eposta adresini kontrol etmesi ( e-posta almak ve göndermek dâhil), internetin suistimal edilmesi olarak tanımlamıştır (Lim, 2002, s. 677). Sanal kaytarma, çalışanların şirket tarafından temin edilen e-posta ve interneti mesai saatlerinde iş dışı amaçla kullanmasıdır (Blanchard ve Henle, 
2008, s. 1068). Sanal kaytarma, bir çalışanın, herhangi bir teknoloji ürününü (bilgisayar, telefon, tablet vb.) yöneticisinin iş ile ilgili olmadığını düşünebileceği zarar verici olmayan bir faaliyet için iş yerinde kullanmasıdır (Askew, 2012, s. 13).

Sanal kaytarma faaliyetlerini daha iyi anlayabilmek için araştırmacılar, sanal kaytarmanın boyutları üzerinde çalışmışlar ve sanal kaytarmayı çeşitli sınıflandırmalara tabi tutmuşlardır. Bu çalışmada Lim ve Teo (2005, s. 1085) tarafindan yapılan sinıflandırma kullanılmıştır.

Internette Gezinme Faaliyetleri (Browsing): Mesai saatleri içerisinde, işletmenin internet erişimini kullanarak işle ilgisi olmayan internet sitelerinde dolaşmak.

E-posta Faaliyetleri (E-Mailing): Mesai saatleri içerisinde, işle ilgisi olmayan e-posta alma, gönderme ve kontrol etme faaliyetlerini kapsamaktadır.

Literatürü incelediğimizde, sanal kaytarma davranışlarını açıklamak için, araştırmacılar tarafından çeşitli teori ve kavramların kullanıldığı görülmektedir. Ego Tükenmesi, Planlı Davranış Teorisi ve Üretkenlik Karşıtı İş Davranışı Teorileri sanal kaytarmayı açıklamak için kullanılan başlıca teorilerdendir.

\section{- $\quad$ Ego Tükenmesi Teorisi}

Ego Tükenmesi Teorisinin (Baumeister vd., 2000) sanal kaytarma çalışmalarında en fazla destek gören teori olduğu söylenebilir (Askew vd., 2014, s. 510). Ego Tükenmesi Teorisi, irade gücünün kas gibi olduğunu yani kullandıkça azalacağını, ancak dinlenince tekrar iyileşeceğini önermektedir. Ego Tükenmesi Teorisi sanal kaytarmayı şu şekilde açıklamaktadır; çalışanlar, irade güçleri tükendiğinde, irade gücünü tekrar elde etmek için sanal kaytarma yapmaktadırlar. (Askew vd., 2014, s. 510) Bu teoriye göre çalışanlar yoruldukları zaman kendilerini yenilemek için sanal kaytarma yoluna başvurmaktadırlar. $\mathrm{Bu}$ teori çeşitli araştırmalarda test edilmiş ve destek görmüştür (Prasad vd., 2010; Wagner vd., 2012; Inzlicht ve Schmeichel, 2012). Ancak teori çalışanların yorgunken sanal kaytarma yapmalarını açılayabilirken, tamamen dinlenmiş durumdayken sanal kaytarma yapma nedenini açıklamada yetersiz kalmıştır.

\section{- $\quad$ Planlı Davranış Teorisi (PDT)}

Askew vd. (2014), Sheikh vd. (2015) ve Taneja vd. (2015), sanal kaytarma davranışlarını açıklarken, Planlı Davranış Teorisini (Theory Of Planned Behavior) kullanmışlardır. Ajzen (1991) tarafından geliştirilen bu teoriye göre, kişilerin davranışlarının altında yatan bazı nedenler bulunmaktadır. Bir davranışın ortaya çıkması için ilk olarak davranışa yönelik niyetin oluşması gerekir. Niyeti etkileyen üç temel unsur bulunmaktadır. Bu unsurlar; kişisel sosyal normlar, tutumlar ve algılanan davranış kontrolüdür. Kişisel sosyal norm, davranışın sergilenmesi ya da sergilenmemesinde algılanan sosyal baskıyı, tutumlar, davranışın kişi tarafindan olumlu ya da olumsuz olarak değerlendirilme derecesi, algılanan davranış kontrolü ise kişi tarafından davranışın sergilenmesindeki zorluk veya kolaylık algısıdır (Örücü ve Özüdoğru, 2018, s. 68). Sonuç olarak çalışanların sanal kaytarma davranışı, kişisel sosyal normlar, tutumlar ve algılanan davranış kontrolünden etkilenmektedir.

\section{- $\quad$ Üretkenlik Karşıtı İş Davranışı Teorisi}

Spector vd. (2006, s. 448) üretkenlik karşıtı iş davranışlarını beş alt boyuta ayırmışlardır. $\mathrm{Bu}$ boyutları; kötüye kullanma, üretimden sapma, hırsızlık, sabotaj ve geri çekilme olarak tanımlamışlardır. Askew vd. (2014, s. 511) sanal kaytarma davranışlarını, Üretkenlik Karşıtı İş Davranışının Geri Çekilme alt boyutu kapsamında değerlendirmişlerdir. Geri Çekilme; çalışanın, işine, örgüt tarafından belirlenen süreden daha az zaman ayırmasıdır (Spector vd., 2006, s. 450). 


\section{2. İşgören Performansı}

İşgörenler, örgütün en önemli unsurlarıdırlar. Bir örgütün başarısı ya da başarısızlığı, işgörenlerin performansıyla doğrudan ilişkilidir. Bireysel performans örgütler için çok önemlidir çünkü işgörenlerin performansı ne kadar iyi olursa, örgütte o kadar iyi olacaktır (Benligiray, 2004, s. 141). Barutçugil (2002, s. 40) tarafından işgören performansı şu şekilde tanımlanmıştır; işgörenlerin gereksinimlerini tatmin etmek amacıyla çalıştıkları kurumda görev ve sorumluluklar üstlenmesi sonucunda, istediklerine ulaşmak için zaman ve çaba harcamasıdır. Rousseau ve McLean (1993, s. 8) tarafından işgören performansı, işgörenlerin alacakları ücretin karşı1lı̆̆ında, sarf etmeleri gereken çaba olarak tanımlanmıştır. İşgörenlerin performansı bireysel olarak arttığı zaman, işletmenin de performansı artacaktır. Performansı yüksek olan işgörenler, örgütsel performansı artırmakta ve bu artışın sonucu olarak işletmeler için hayati öneme sahip rekabet gücü de artmaktadır (Turunç, 2010, s. 253-254). Bu kapsamda örgüt yöneticilerinin işgörenlerin performansını arttırmaları gerekmektedir (Kesen ve Sipahi, 2016, s. 1929).

İşgörenlerin performansını birçok faktör etkileyebilmektedir. İşgören performansını etkileyen unsurlar Aydın (2010, s. 31) tarafından İş Tatmini, Çevresel Faktörler, Motivasyon ve Stres olmak üzere dört başlık altında incelenmiştir.

İş tatmini, işgörenlerin, işlerinin farklı yönlerine karşı beslemiş oldukları tutumların toplamıdır. Bu kapsamda, çalışanın işine karşı tutumu olumlu ise iş tatmini de olmaktadır; aksi durumda ise tatminsizlik ortaya çıkmaktadır. Bu bağlamda iş tatmini; bir işgörenin işine bakışı, işiyle ilgili rasyonel ve duygusal tepkileri ya da işi hakkında yaptığ 1 değerlendirmelerin sonucudur (Çarıkçı, 2001, s. 162). İşgörenin, işinden tatmini yeterli düzeydeyse, verimli çalışacak, fire ve işgücü devir oranı azalabilecektir (Baysal ve Tekarslan, 1996, s. 281).

Performans1 etkileyen temel unsurlardan bir diğeri olan çevresel faktörler, fiziksel ve organizasyonel faktörler olmak üzere ikiye ayrılmaktadır. Aydınlatma, 1sıtma, gürültü, örgütte kullanılan araçlar, havadaki oksijen miktarının düzeyi, rutubet, yardımcı araç ve gereçler, havanın kalitesi gibi unsurlar işgören performansını etkileyen fiziksel özellikler olarak sayılabilir (Üçüncü vd, 2008). Örgüt yapısı, takip edilen strateji, örgütteki yetki ve görev dağılımı, işgörenlerin çalışma koşulları ise başlıca organizasyonel faktörlerdendir (Bulut, 2003, s. 10).

İşgören motivasyonu ile performans yakından ilişkilidir (Aydın, 2010, s. 38). Yöneticinin, işgörenleri örgüt amaçları doğrultusunda yönlendirmesi ise ancak motivasyon ile olabilecektir. Örgütsel hedeflere ulaşabilmek için işgörenleri çok çalışmaya teşvik etmek tüm yönetimlerin karşılaştığı zorluklardandır. Motivasyonu üst düzeyde olan işgörenler, örgütün belirlediği amaçlara ulaşabilmesindeki en önemli unsurdur (Öğüt vd., 2004, s. 1).

Baltaş (1996, s. 221) tarafından işgörenlerin performansını etkileyen unsurlardan biri olan stresin tanımı şu şekilde yapılmaktadır; organizmanın fiziksel ve ruhsal sınırlarının tehdit edilmesi ve zorlanmasi ile meydana gelen ve etkilerini psikolojik ve toplumsal seviyelerde gözlemlenebilen bir durumdur. Literatürde iş stresinin performans üzerinde olumlu ve olumsuz etkileri olduğu tespit edilmiştir. Optimum düzeydeki bir stres, işgöreni motive ederek performansının artmasına neden olurken, aşırı stres ise performansının azalmasına ve başarısızlığa neden olabilmektedir. Bu durum örgütler için yüksek maliyetlere neden olmaktadır (Patel, 1989, s. 2).

\section{3. İş Stresi}

Stres sözcügü, günümüzde sıkça kullanılan kelimelerden birisi olarak karşımıza çıkmaktadır. İngilizcede "kaygı", "keder", "acı" anlamına gelen "distress" kelimesinin kısaltması olan stres kelimesinin kökeni, Latince "çekilmiş", gerilmiş" anlamına gelen "strictus" ve Eski Fransızca "darlık", "bask1" anlamına gelen "estresse" kelimelerine dayanmaktadır (Oxford Dictionary, 2018). Stresin varlığını kanıtlayan ilk kişi olarak görülen Hans Selye tarafından stres şu şekilde tanımlanmıştır; stres, vücudun herhangi bir talebe karşı göstermiş 
olduğu belirgin olmayan yanıttır. Stres, kişinin fiziksel ve sosyal çevredeki uyumsuz koşullar nedeniyle, bedensel ve psikolojik sınırlarının ötesinde sarf ettiği gayrettir (Cüceloğlu, 1994, s. 321). Stres, bireylerin huzuru için bir tehlike işareti ve uyarı olarak algılanan olaylara gösterilen fizyolojik ve psikolojik tepkidir (Şimşek, Akgemci ve Çelik, 2008, s. 329). Stres, işletmelerin başarısında önemli bir role sahip olan, örgütsel davranış konularından birisidir (Nart ve Yıldırım, 2018, s. 7). İş stresini açıklamak üzere araştırmacılar tarafından literatürde çeşitli teoriler kullanılmıştır. Bu teorilerden bazıları aşağıda incelenmiştir.

\section{- $\quad$ Işs Talepleri - Kontrol Teorisi (The Job Demands - Control Model)}

Literatürde iş stresi ile ilgili sık kullanılan teorilerden biri olan İş Talepleri - İş Kontrolü teorisi Karasek (1979, s. 285) tarafından ortaya atılmıştır. Bu teorideki iş talebi kavramı, iş yerinde strese neden olan faktörleri ifade etmektedir. İş kontrolü ise iki boyuttan oluşmaktadır. Bunlardan birincisi, çalışanın yaptığı işiyle ilgili karar alma yeteneği ve özgürlüğü, ikincisi ise çalışanın işiyle ilgili beceri ve yaratıcılık seviyesidir. Bu iki boyut karar serbestisini (decision latitude) oluşturmaktadır. Teoriye göre iş talebinin yüksek, çalışanın karar serbestisinin düşük olduğu durumlarda stresin en yüksek seviyede olması beklenmektedir. Bu stres hipotezi olarak (strain hypotheses) adlandırılmaktadır. İş talebinin yüksek, çalışanın karar serbestisinin de yüksek olduğu durumlarda ise çalışan için olumlu sonuçlar ortaya çıkmaktadır. Talebin sonuçlar üzerindeki etkisi açısından kontrolün tampon görevi görmesi nedeniyle bu durum tampon hipotezi (buffer hypotheses) olarak adlandırılmaktadır (Güleryüz ve Aydın, 2006, s. 60).

\section{- $\quad$ Kişi Çevre Uyumu Modeli (Person - Environment Fit Model)}

$\mathrm{Bu}$ teori Michigan Üniversitesi Sosyal Bilimler Araştırma Grubu tarafından ABD'de geliştirilmiştir (Caplan vd., 1975). Kişi Çevre Uyumu Modeline göre stres, işin talepleri ve gereksinimleri ile kişinin bu talepleri karşılamak için algıladığ 1 kendi yeteneği arasındaki uyumsuzluktur (Ampadu, 2015, s. 25). Bu model kapsamında Bogg ve Cooper (1995, s. 329), stresi, kişinin nitelikleri (yetenekler, değerler vb.) ile çevre (talepler vb.) arasındaki uyum eksikliği olarak tanımlamışlardır. Teoriye göre kişi ve çevre arasındaki algılanan uyum fiziksel ve psikolojik sağlığa katkı sağlarken, algılanan uyumsuzluk ise strese neden olmaktadır (Edwards ve Rothbard, 1999, s. 87). Kişi Çevre Uyumu Modeline göre uyum eksikliği bazı fizyolojik (kan basıncının yükselmesi) ve psikolojik (uyku bozukluğu, panik atak, isteksizlik) belirtilere neden olabilmektedir (Harrison, 1978, s. 176).

Stresör, strese neden olan faktörlere denir. Literatürde stresörlerin belirlenmesi için birçok araştırma ve sınıflandırma yapıldığı görülmektedir. Stresörler, bu çalışma kapsamında fiziksel çevre, örgütsel faktörler ve bireysel faktörler şeklinde sınıflandırılmıştır.

Fiziksel çevre, çalışanların işyerinde geçirdiği süre göz önüne alındığında, bulundukları fiziki ortamdan etkilenmemeleri de imkânsız hale gelmektedir. İş ortamındaki fiziksel koşulların iyi ya da kötü olması iş stresine neden olan faktörler arasında gösterilmektedir. Gürültü, iş ortamının sıcaklığı ve aydınlatma çalışanları etkileyen başlıca fiziksel etkenler olarak ön plana çıkmaktadır. Örgütsel faktörler, mesleki farklılıklar, rol belirsizliği, rol çatışması, aşırı iş yükü veya az çalışma işgörenlerde strese neden olan örgütsel faktörler olarak değerlendirilmektedir. Bireysel faktörler, kişilik özelliği strese neden olan en önemli bireysel faktörlerden birisidir. Kişilik özellikleri dışında, algılama farklılıkları, aile ilişkilerinin bozuk olması, sahip olunan tecrübeler, boşanma, ölüm, taşınma ve ekonomik problemler işyerindeki strese neden olan diğer bireysel faktörlerdir (Sabuncuoğlu ve Tüz, 2001, s. 240).

\subsection{Araştırma Değişkenleri Arasındaki İlişkilerin İncelenmesi}

\subsection{1. İs Stresi ve İşgören Performansı Arasındaki İlişki}

Stres ve performans arasındaki ilişkiyi araştıran çalışmalarda dört farklı sonucun ortaya çıktığı görülmektedir (Gümüştekin ve Öztemiz, 2005, s. 283). Birincisi, stresin aşırı yüksek ve aşırı düşük olduğu durumlarda performans azalırken, stresin normal düzeyde olduğu durumlarda 
performans artmaktadır. İkincisi, stres ile performans doğru orantılıdır. Stres arttıkça performansta artış göstermektedir. Üçüncüsü, stres ile performans ters orantılıdır. Stres azaldıkça performans artmaktadır. Dördüncüsü, stres ile performans arasında bir ilişki bulunmamaktadır. Literatürde iş stresi ile performans arasındaki ilişkiyi araştıran çalışmalardan bazıları aşağıda incelenmiştir.

Tekingündüz, Kurtuldu ve Eğilmez (2016) yaptıkları araştırmalarında sağlık çalışanlarının performansları ile iş stresleri arasındaki ilişkiyi incelemişlerdir. Araştırmanın örneklemi 583 sağlık çalışanından oluşmaktadır. Araştırmanın bulgularına göre sağlık çalışanlarının performansları ile iş stresleri arasında anlamlı bir ilişki olmadığı tespit edilmiştir. Abualrub ve Al-Zaru (2008) tarafindan Ürdünlü hemşireler üzerine yapılan araştırmada da iş stresi ile performans arasında anlamlı bir ilişki olmadığı tespit edilmiştir.

Shahid vd. (2011) araştırmalarında, iş stresi ile işgören performansı arasındaki ilişkiyi incelemişlerdir. Çalışanlar arasındaki zayıf iletişim, aşırı iş yükü ve riskli bir iş yapmaları, banka çalışanlarının iş stresine neden olan en önemli faktörler olarak tespit edilmiştir. Çalışanların iş yükü ve zaman baskısı nedeniyle, iş ve aile hayatlarını yönetemediği ve bazı sosyal problemlerle karşılaştıkları belirtilmiştir. Sonuç olarak aşırı stresli işin, işgören performansını düşürdüğü tespit edilmiştir.

Alkan (2014) yaptığı araştırmasında, doktorların performansları ile iş stresleri arasındaki ilişkiyi incelemiştir. Araştırmanın verileri bir kamu hastanesinde görevli 156 doktordan elde edilmiştir. Araştırma sonucunda sağlık çalışanlarının iş stresi ile performansları arasında negatif yönlü ve anlamlı bir ilişki olduğu tespit edilmiştir.

Zafar vd. (2015) çalışmalarında iş stresi ile işgören performansı arasındaki iliş̧iyi araştırmışlardır. Araştırma sonucunda iş stresi ile iş performansı arasında pozitif yönlü bir ilişki olduğu tespit edilmiştir.

Literatürde stres ile performans arasındaki ilişkiyi açıklamak için kullanılan çeşitli teoriler bulunmakla birlikte, Negatif Yönlü Doğrusal Teori (The Negative Linear Theory) ön plana çıkmaktadır (Muse vd., 2003). Bu teoriye göre stres ile performans ters orant1lıdır. Stres azaldıkça performans artmaktadır. Negatif Yönlü Doğrusal Teori ve literatürdeki çalışmalar 1şığında iş stresi ve işgören performansı arasındaki ilişki üzerine geliştirilen hipotez şu şekildedir:

\section{"H1: İ̧s stresinin işgören performansı üzerinde anlamlı ve negatif yönde etkisi vardır."}

\subsubsection{Sanal Kaytarma ve İşgören Performansı Arasındaki İlişki}

Literatürde sanal kaytarma ile işgören performansı arasındaki ilişkiyi inceleyen çalışmalara bakıldığında farklı sonuçların elde edildiği görülebilmektedir. Bazı çalışmalarda sanal kaytarma davranışlarının performansı olumlu etkilediği, bazılarında ise olumsuz etkilediği belirtilmektedir. Bu iki değişken arasındaki ilişkiyi araştıran çalışmalardan bazıları aşağıda incelenmiştir.

Afacan Findıklı (2016) yaptığı araştırmasında sanal kaytarma davranışlarının performans üzerindeki etkisini incelemiştir. Araştırma verileri sağlı ve tekstil sektörlerinde çalışan 406 katılımcıdan elde edilmiştir. Araştırma sonucunda sağlık sektöründe çalışanların, tekstil sektöründe çalışanlara göre daha az sanal kaytarma yaptığı tespit edilmiştir. Ayrıca sağlık sektöründe çalışanların sanal kaytarma davranışları arttığında performanslarının azaldığı tespit edilmiştir.

Garrett ve Danziger (2008) yaptıkları araştırma kapsamında sanal kaytarma davranışlarının sonuçlarını incelemişlerdir. Araştırma sonucunda iş yerinde internet kullanımı yani sanal kaytarma ile performans arasında olumlu bir ilişki olduğunu tespit etmişlerdir. 
Bilgin Demir, Ürek ve Uğurluoğlu (2017) tarafından yapılan araştırma kapsamında sağlık çalışanlarının sanal kaytarma davranışları ile performansları arasındaki ilişki incelemiştir. Araştırmanın verileri 259 sağlık çalışanından elde edilmiştir. Araştırma sonucuna göre sanal kaytarmanın alt boyutları olan önemli ve önemsiz sanal kaytarma davranışlarının performansı olumsuz etkilediği tespit edilmiştir.

Santos (2016) yaptığı çalışmasında sanal kaytarma davranışları ile işgören performansı arasındaki ilişkiyi incelemiştir. Deneysel araştırma yönteminin kullanıldığı araştırmanın sonucunda, sanal kaytarma davranışlarının, işgörenlerin hem fiziksel hem zihinsel performanslarını olumsuz etkilediği tespit edilmiştir.

Sanal kaytarma faaliyetleri Üretkenlik Karşıtı İş Davranışı Teorisi kapsamında Geri Çekilme davranışı olarak değerlendirilmektedir. Geri Çekilme Davranışı, çalışanın, işine örgüt tarafından beklenenden daha az süre ayırması olarak tanımlanmaktadır. Sonuç olarak sanal kaytarma yapan kişilerin beklenenden daha az süre performans göstermeleri nedeniyle, performanslarının negatif yönde etkilenebileceği öngörülebilir. Üretkenlik Karşıtı İş Davranışı Teorisi ve literatürdeki çalışmalar kapsamında sanal kaytarma ve işgören performansı arasındaki iliş̧ki üzerine geliştirilen hipotezler şu şekildedir:

"H2: Sanal kaytarma davranışlarının işgören performansı üzerinde anlamlı ve negatif yönde etkisi vardır."

"H2a: Sanal kaytarma davranıslartnın alt boyutu olan internette gezinme (browsing) faaliyetlerinin işgören performansı üzerinde anlamlı ve negatif yönde etkisi vardır."

"H2b: Sanal kaytarma davranışlarının alt boyutu olan e-posta faaliyetlerinin işgören performanst üzerinde anlamlı ve negatif yönde etkisi vardır."

\subsubsection{Sanal Kaytarma ve İş Stresi Arasındaki İlişki}

İş yerinde kişisel internet kullanımı olarak tanımlanan sanal kaytarmanın işgörenler üzerindeki stresi azaltması, bu davranışın olumlu etkilerinden biri olarak görülmektedir. Vitak vd. (201, s. 1752) kısa süreli sanal kaytarmanın işgören üzerinde sıkıntı, bitkinlik ve stresten kurtulma, daha fazla iş memnuniyeti, daha mutlu hissetme ve yenilenme gibi olumlu etkileri olabileceğini belirtmişlerdir. Anandarajan ve Simmers (2005, s. 777) sanal kaytarmanın iş yerinde stresi azaltan ve ilham veren bir oyuncak olduğunu belirtmektedirler. Literatürde iş stresi ile sanal kaytarma arasındaki ilişkiyi araştıran çeşitli çalışmalar yapıldı̆̆ görülmektedir.

Şen vd. (2016) çalışmalarında iş stresinin sanal kaytarma davranışları üzerindeki etkisini araştırmışlardır. Araştırma kapsamında sanal kaytarma davranışlarının siniflandirılmasinda Mahatanankoon vd. (2004, s. 95) tarafindan yapilan siniflandirma baz alınmıştır. Bu sınıflandırmaya göre sanal kaytarma davranışları dört sınıfa ayrılmıştır: Bunlar; internetin rahatlama amaciyla kullanımı, internetin suistimal edilmesi ya da zarar verici sanal kaytarma, kendini geliştirme amacıyla internet kullanımı ve belirsiz internet kullanımıdır. Araştırma sonucunda elde edilen bulgulara göre iş stresi arttıkça, internetin rahatlama amacıyla kullanımı ile internetin suistimal edilmesinin de arttığ kendini geliştirmek amacıyla internetin kullanılması ve belirsiz internet kullanımı artmaktadır.

Koay, Soh ve Chew (2017) yaptıkları araştırma kapsamında sanal kaytarma ile iş stresi arasındaki ilişkiyi incelemişlerdir. Araştırma sonucunda yüksek düzeyde iş stresinin sanal kaytarma davranışlarına neden olduğu tespit edilmiştir. Çalışanların iş stresi ile mücadele etmek için interneti kişisel amaçları için kullandığ tespit edilmiştir. Garrett ve Danziger (2008, s. 950) tarafından yapılan araştırmada da yüksek düzeyde iş stresinin sanal kaytarma davranışlarına neden olduğu belirtilmiştir.

Çivilidağ (2017) tarafından yapılan araştırmada sanal kaytarmanın iş stresi ile ilişkisi incelenmiştir. Araştırma sonucunda sanal kaytarmanın alt boyutları olan önemli ve önemsiz 
sanal kaytarma ile iş stresi arasında düşük düzeyde olumlu ve anlamlı olmayan bir ilişki bulunmuştur.

Henle ve Blanchard (2008) tarafından yapılan araştırmada iş stresi ile sanal kaytarma arasındaki ilişki incelenmiştir. Çalışmanın sonucunda iş stresinin alt boyutu olan çalışanların rol belirsizliği algısı ile rol çatışması algısı arttı̆̆ında sanal kaytarma yapma olasılıkları da artmaktadır. Ancak iş stresinin bir diğer alt boyutu olan algılanan iş yükü arttı̆̆ında sanal kaytarma yapma olasılığının azaldığı tespit edilmiştir.

Literatürdeki çalışmalar kapsamında sanal kaytarma ve iş stresi arasındaki ilişki üzerine geliştirilen hipotezler şu şekildedir: vardır."

"H3: Sanal kaytarma davranışlarının iş stresi üzerinde anlamlı ve pozitif yönde etkisi

"H3a: Sanal kaytarma davranıslarinin alt boyutu olan internette gezinme (browsing) faaliyetlerinin iş stresi üzerinde anlamlı ve pozitif yönde etkisi vardır."

"H3b: Sanal kaytarma davranışlarının alt boyutu olan e-posta faaliyetlerinin iş stresi üzerinde anlaml ve pozitif yönde etkisi vardır."

\subsubsection{Sanal Kaytarma, İşgören Performanst ve İş Stresi Arasındaki İlişki}

Türkçe ve İngilizce literatür taraması sonucunda sanal kaytarma, işgören performansı ve iş stresi değişkenleri arasındaki ilişkiyi inceleyen bir araştırmaya rastlanmamıştır. Araştırma kapsamında sanal kaytarma bağımsız değişken, işgören performansı bağımlı değişken ve iş stresi düzenleyici değişken olarak belirlenmiştir. Bu üç değişken arasındaki ilişki literatürde ilk kez incelenecektir.

Sanal kaytarma davranışlarının işgören performansı üzerindeki etkisini inceleyen çalışmalarda farklı sonuçların ortaya çıktığı görülmektedir. Bazı çalışmalarda bu davranışların performansı olumlu etkilediği, bazı çalışmalarda ise olumsuz etkilediği tespit edilmiştir. Oravec (2002, s. 61) sanal kaytarma davranışlarının işgörenler üzerinde bir yenileme etkisi olduğu ve sonraki görevlerde daha iyi performans göstermesine neden olduğunu belirtmiştir. Santos (2016) ise sanal kaytarmanın işgörenlerin hem fiziksel hem de zihinsel performanslarını düşürdüğünü tespit etmiştir. Sanal kaytarma davranışlarının işgören performansı üzerindeki etkisi konusunda araştırmacılar arasında fikir ayrılığı olduğu görülebilmektedir.

İş stresi aşırı yüksek ve aşırı düşük olduğu durumlarda performansı olumsuz yönde etkilerken, normal düzeyde olduğu durumlarda ise performans olumlu yönde etkilenmektedir (Gümüştekin ve Öztemiz, 2005, s. 283). Araştırmanın örneklemini oluşturan sağlık personelinin yoğun stres altında çalıştığı belirtilmektedir (Şahin ve Batıgün, 1997, s. 62). Sağlık personelinin sanal kaytarma davranışlarının performansları üzerindeki etkisinde, iş stresinin düzenleyici etkisi olduğu öngörülebilir.

Üretkenlik Karşıtı İş Davranışı Teorisine göre sanal kaytarma faaliyetleri performansı azaltmaktadır. Negatif Yönlü Doğrusal Teoriye göre ise stres arttıkça performans azalmaktadır. Sonuç olarak sanal kaytarma ile işgören performansı arasındaki ilişkide, iş stresinin düzenleyici etkisinin olabileceği, yani bağımsız değişken (sanal kaytarma) ile bağımlı değişken (işgören performans1) arasındaki ilişkinin şiddetini etkileyeceği öngörülebilir. İş stresi ve işgören performansı ile ilgili yukarıda verilen bilgiler ve literatürdeki çalışmalar ışığında aşağıdaki hipotezler geliştirilebilir:

"H4: Sanal kaytarma ve işgören performansı ilişkisi üzerinde, iş stresinin düzenleyici etkisi vardır."

"H5: Sanal kaytarma davranıslarınin alt boyutu olan internette gezinme (browsing) faaliyetleri ile işgören performansı ilişkisi üzerinde, iş stresinin düzenleyici etkisi vardır.” 
"H6: Sanal kaytarma davranışlarının alt boyutu olan e-posta faaliyetleri ile işgören performansı ilişkisi üzerinde, işstresinin düzenleyici etkisi vardır."

\section{Araştırmanın Problemi, Amacı ve Önemi}

$\mathrm{Bu}$ araştırmanın amacı, sanal kaytarma davranışları ile işgörenlerin performansları arasındaki ilişkiyi ve bu ilişki üzerinde iş stresinin düzenleyici (moderatör) etkisini incelemektir. Bu amacı gerçekleştirebilmek için araştırma kapsamında aşağıdaki sorulara yanıt aranmıştır;

Sanal kaytarma ile işgören performansı arasında bir ilişki var mıdır?

İş stresi ile sanal kaytarma arasında bir ilişki var mıdır?

İş stresi ile işgören performansı arasında bir ilişki var mıdır?

Sanal kaytarma ile işgören performansı arasındaki ilişkide iş stresinin düzenleyici bir etkisi var midır?

Araştırmada sanal kaytarma, işgören performansı ilişkisinde iş stresinin düzenleyici etkisi incelenmektedir. Literatürde, değişkenler arasındaki bu ilişkiyi araştıran bir çalışma bulunmaması, bu çalışmayı önemli kılan en önemli nedendir. Ayrıca literatürde sanal kaytarma ile iş stresi arasındaki ilişkiyi araştıran sınırlı sayıda çalışmanın bulunması da araştırmayı önemli kılan bir diğer nedendir.

\section{Araştırmanın Yöntemi}

Çalışmada anket yöntemi ile toplanan veriler üzerinden araştırma hipotezlerinin test edilmesine dayanan nicel araştırma yöntemi benimsenmiştir. Toplanan veriye ilişkin analizler ve hipotez testleri istatistiksel veri analiz programı yardımıyla gerçekleştirilmiştir. Çalışmanın bu bölümünde araştırma yöntemi ve kullanılan analiz teknikleri ile ilgili bilgiler verilmektedir. $\mathrm{Bu}$ kapsamda araştırma modeli açıklanmıştır. Daha sonra araştırmanın evreni, örneklemi ve kullanılan örnekleme yöntemi ile ilgili bilgiler verilmiştir. Ayrıca, araştırmada kullanılan veri toplama yöntemi ve teknikleri ile araştırmada kullanılan ölçekler hakkında açıklayıcı bilgiler verilmiştir.

\subsection{Araştırmanın Kapsamı ve Modeli}

$\mathrm{Bu}$ araştırmanın amacı, sanal kaytarma ile işgören performansı arasındaki ilişkide iş stresi etkisinin ne seviyede olduğunun belirlenmesidir. Bu kapsamda katılımcıların sanal kaytarma davranışları ve işgören performansı arasında bir ilişki olduğu, iş stresinin de bu ilişkide düzenleyici etkisinin olduğu varsayılmaktadır. Bu varsayımdan yola çıkarak sanal kaytarma, işgören performansı ve iş stresi değişkenleri arasında oluşturulan araştırma modeli Şekil 1'de sunulmuştur.

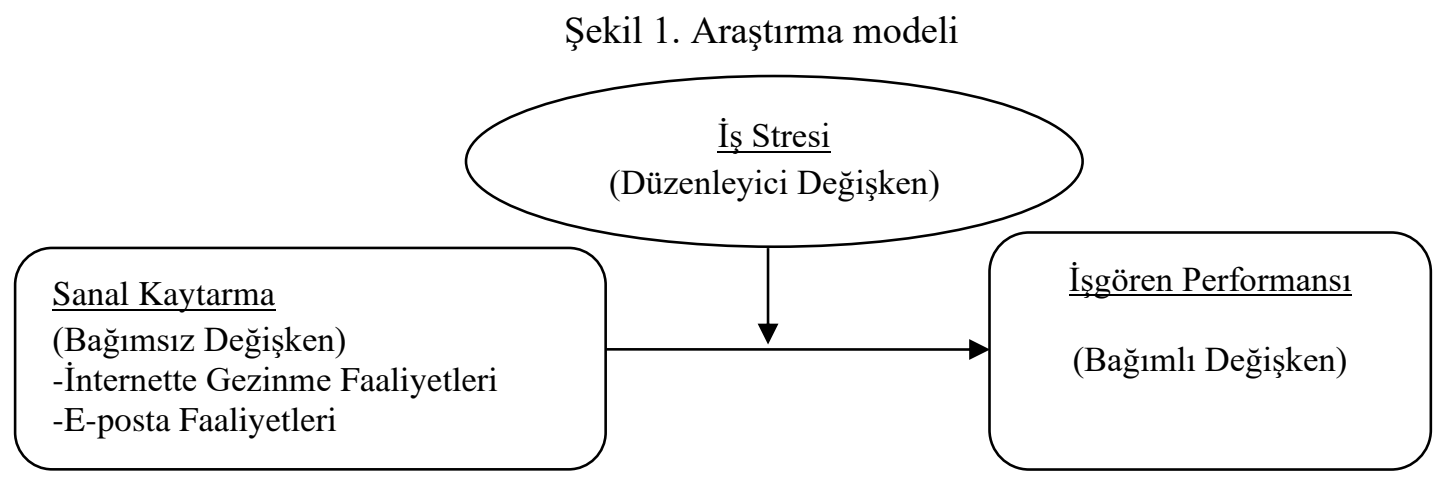

Modele göre, sanal kaytarma davranışları internette gezinme faaliyetleri (browsing) ve e-posta faaliyetleri olmak üzere iki alt boyut olarak değerlendirilmiştir. İşgören performansı ve iş stresi değişkenleri ise tek boyutta değerlendirilmiştir. Oluşturulan modelde, sanal kaytarma ile işgören performansı arasındaki ilişkinin varlığı sorgulanmakta olup, sanal kaytarma değişkeni bağımsız değişken, işgören performansı ise bağımlı değişken olarak değerlendirilmiştir. İş 
stresinin söz konusu ilişki üzerinde düzenleyici etkisinin olduğu öngörüldüğü için iş stresi düzenleyici değişken olarak değerlendirilmiştir.

\subsection{Evren ve Örneklem}

Araştırmanın evrenini, Balıkesir ilindeki kamuya ait sağlık kuruluşlarında görevli çalışanlar oluşturmaktadır. Evrendeki tüm bireylere ulaşılması mümkün olmadığı için örnekleme yapılması zorunlu görülmüştür. Örnekleme yöntemi olarak tesadüfi olmayan örnekleme yöntemlerinden kolayda örnekleme metodu tercih edilmiştir. Ancak, örneklemin evreni en iyi şekilde temsil edebilmesi için mümkün olduğunca farklı özellikteki bireylere ulaşılmaya çalışılmıştır. Kolayda örnekleme metodu ile 436 katılımcıya ulaşılmıştır. Bu katılımcılara uygulanan anketlerin 34 tanesi işaretleme hataları ve eksik işaretleme nedeniyle geçersiz sayılmış ve 402 adet anket değerlendirmeye tabi tutulmuştur. Balıkesir ilinde görevli sağlık sektörü çalışanlarının sayısı, 2017 yılında yayınlanan, Sağlık Bakanlığı Sağlık İstatistikleri Yılllğı - 2016'ya göre 7887 olarak tespit edilmiştir. Gürbüz ve Şahin (2016, s. 131), 8000 kişiden oluşan bir evrenin, en az 367 kişiden oluşan bir örneklem tarafından temsil edebileceğini belirtmektedirler. Sonuç olarak 402 kişiden oluşan araştırma örnekleminin yeterli düzeyde olduğu söylenebilir.

\subsection{Araştırmanın Veri Toplama Tekniği ve Aracı}

Araştırmada veri toplama yöntemi olarak anket uygulaması kullanılmıştır. Hazırlanan anket formu, sağlık çalışanlarının sanal kaytarma davranışlarını, performanslarını ve iş streslerini ölçmek amacıyla daha önceki araştırmalarda kullanılan ölçekler ile katılımcılara ait demografik bilgileri elde etmeyi amaçlayan sorulardan oluşmuştur. Demografik sorular hariç, diğer üç ölçekte cevaplar 5'li likert ölçeği ile alınmıştır. Anket formu 4 bölümden ve toplam 30 sorudan oluşmaktadır.

Anket formunun birinci bölümü katılımcıların demografik özelliklerini tespit etmeye yönelik 5 sorudan (cinsiyetiniz, yaşınız, medeni durumunuz, eğitim durumunuz, mesleğiniz) oluşmaktadır.

Anket formunun ikinci bölümünde işgörenlerin performanslarını ölçmek için kullanılan, Kirkman ve Rosen (1999) tarafından geliştirilen ve Çöl (2008) tarafından Türkçe 'ye uyarlanan "İşgören Performans1 Ölçeği” bulunmaktadır. İşgören Performansı Ölçeği tek boyut ve 4 sorudan (1 ve 4. madde) oluşmaktadır.

Anket formunun üçüncü bölümünde katılımcıların sanal kaytarma davranışlarını ölçmek için kullanılan, Lim ve Teo (2005) tarafından geliştirilen "Sanal Kaytarma Ölçeği" bulunmaktadır. Ölçek İnternette Gezinme Faaliyetleri (Browsing) ve E-posta Faaliyetleri (Emailing) olmak üzere iki alt boyuttan ve toplam 13 sorudan (5-17. madde) oluşmaktadır. İnternette Gezinme Faaliyetleri, e-posta faaliyetleri dışındaki, genel internet faaliyetlerini kapsamaktadır ve bu alt boyut 10 sorudan (5-14. madde) oluşmaktadır. E-posta Faaliyetleri, kişisel e-posta alma, gönderme ve kontrol etme faaliyetlerini kapsamaktadır ve 3 sorudan (15 17. madde) oluşmaktadır.

Anket formunun dördüncü bölümünde, katılımcıların iş stresini ölçmek için kullanılan, House ve Rizzo (1972) tarafından geliştirilen ve Efeoğlu (2006) tarafindan Türkçe'ye uyarlanan "İş Stresi Ölçeği” bulunmaktadır. İş Stresi Ölçeği tek boyut ve 7 sorudan (18 - 24.madde) oluşmaktadır.

\section{4. Çalışmanın Analizleri ve Bulgular}

Araştırmanın bu kısmında, elde edilen verilerin analiz edilmesi sonucunda ortaya çıkan bulgulara yer verilmiştir. Öncelikle katılımcılara ait demografik bulgular paylaşılmıştır. Daha sonra araştırmada kullanılan ölçeklere ait güvenirlik analizi sonuçları, değişkenlerin faktör analizine uygunluğunu gösteren Kaiser-Meyer-Olkin (KMO) ve Bartlett's Küresellik Testlerinin sonuçları, ölçeklere ait faktör analizi sonuçları ile elde edilen verilere uygulanacak istatistiksel 
analizlerin belirlenmesi için kullanılan Normallik Testi sonuçları paylaşılmıştır. Ayrıca, değişkenler arasındaki ilişkilerin belirlenmesinde kullanılan, Korelasyon ve Regresyon analizlerinin sonuçlarına yer verilmiştir.

\subsection{Demografik Değişkenlere İlişsin Bulgular}

Araştırmaya katılan 402 sağlık çalışanının demografik özellikleri cinsiyet, yaş gurubu, medeni durumu, eğitim durumu ve mesleği şeklinde olmak üzere beş başlık altında incelenmiştir. Tablo 1'de sunulan veriler kapsamında araştırmaya katılan 402 sağlık çalışanın \%55,5'inin kadın, \% 44,5'inin erkek olduğu görülmektedir. Katılımcıların \%25,6'sının 25 yaşın altında, \%33,1'inin 26-35 yaş aralığında, \%30,3'ünün 36-45 yaş aralığında, \%10,0'unun 46-55 yaş aralığında ve \%1,0'inin 56 yaş ve üstünde olduğu görülmektedir. Katılımcıların \%61,9'unun evli, \%38,1'inin bekâr olduğu görülmektedir. Eğitim durumuna bakıldığında ilköğretim mezunlarının oranı $\% 4,0$, lise mezunlarının oran $\% 21,4$, üniversite mezunlarının oran $\% 64,4$, yüksek lisans mezunlarının oran $1 \% 8,5$ ve doktora mezunlarının oranı $\% 1,7$ 'dir. Katılımcıların \%8,7'sinin doktor, \%39,1'inin hemşire, \%19,2'sinin sağlık memuru / teknisyen, \%15,9'unun idari personel, \%17,2'sinin diğer sağlik personeli olduğu görülmektedir. Demografik değişkenlere ait bulgular Tablo 1'de sunulmuştur.

Tablo 1. Demografik değişkenlere ait bulgular

\begin{tabular}{llll}
\hline \multicolumn{1}{c}{ Değişkenler } & \multicolumn{1}{c}{ Gruplar } & Frekans (n) & Yüzde (\%) \\
\hline \multirow{3}{*}{ Cinsiyet } & Kadın & 223 & 55,5 \\
& Erkek & 179 & 44,5 \\
& Toplam & 402 & 100,0 \\
\hline \multirow{4}{*}{ Yaş } & 25 ve altı & 103 & 25,6 \\
& $26-35$ & 133 & 33,1 \\
& $36-45$ & 122 & 30,3 \\
& $46-55$ & 40 & 10,0 \\
& 56 ve üzeri & 4 & 1,0 \\
\multirow{3}{*}{ Medeni Durum } & Toplam & 402 & 100,0 \\
\hline \multirow{5}{*}{ Eğitim Durumu } & Evli & 249 & 61,9 \\
& Bekâr & 153 & 38,1 \\
& Toplam & 402 & 100,0 \\
\hline & İlköğretim & 16 & 4,0 \\
& Lise & 86 & 21,4 \\
& Üniversite & 259 & 64,4 \\
& Yüksek Lisans & 34 & 8,5 \\
& Doktora & 7 & 1,7 \\
& Toplam & 402 & 100,0 \\
\hline \multirow{5}{*}{ Meslek } & Doktor & 35 & 8,7 \\
& Hemşire & 157 & 39,1 \\
& Sağlı Memuru / Teknisyen & 77 & 19,2 \\
& İdari Personel & 64 & 15,9 \\
& Diğer Sağlık Personeli & 69 & 17,2 \\
& Toplam & 402 & 100,0 \\
\hline
\end{tabular}

\subsection{Güvenirlik Analizine İlişkin Bulgular}

İç tutarlılık analizinde farklı hesaplama yöntemleri kullanılmaktadır. Bu çalışma kapsamında ise ölçeklerin iç tutarlılık analizinde Cronbach (1951) tarafindan geliştirilen Alpha $(\alpha)$ katsayısı yöntemi kullanılmıştır. Araştırmada kullanılan ölçeklere ait güvenirlik analizleri, ortalamalar ve standart sapmalar Tablo 2'de sunulmuştur. 
Tablo 2. Ölçeklere ait güvenirlik katsayıları, ortalamalar ve standart sapmalar

\begin{tabular}{lcccc}
\hline Ölçek/Alt Boyut & $\begin{array}{c}\text { Madde } \\
\text { Sayıs }\end{array}$ & $\begin{array}{c}\text { Cronbach's } \\
\text { Alpha }\end{array}$ & Ortalama & $\begin{array}{c}\text { Standart } \\
\text { Sapma }\end{array}$ \\
\hline Sanal Kaytarma Ölçeği & 13 & 0,928 & 2,4661 & 0,926 \\
İnternette Gezinme Faaliyetleri Alt Boyutu & 10 & 0,902 & 2,4567 & 0,905 \\
E-posta Faaliyetleri Alt Boyutu & 3 & 0,932 & 2,4975 & 1,264 \\
İşgören Performansi Ölçeği & 4 & 0,922 & 3,7065 & 1,004 \\
İş Stresi Ölçeği & 7 & 0,869 & 3,2594 & 0,920 \\
\hline
\end{tabular}

Ölçek maddeleri arasındaki iç tutarlılık değerini gösteren Cronbach Alpha katsayının 0,70 ve üzerinde olması durumunda, ölçeğin güvenilir olduğu kabul edilmektedir (Nunnaly, 1978, s. 245). Tablo 2'de görüldüğü gibi araştırmada kullanılan sanal kaytarma ölçeği $(0,928)$, işgören performansı ölçeği $(0,922)$ ve iş stresi ölçeğinin $(0,869)$ Cronbach Alpha değerleri 0,70 değerinin üzerindedir. $\mathrm{Bu}$ kapsamda araştırmada kullanılan ölçeklerin güvenilir olduğu söylenebilir.

\subsection{Kaiser-Meyer-Olkin (KMO) ve Bartlett's Küresellik Testleri}

Faktör analizinden önce değişkenlerin faktör analizi için uygun olup olmadığını test etmek için Kaiser-Meyer-Olkin (KMO) ve Bartlett's Küresellik testinin uygulanması gerekmektedir. KMO testi değişkenlerin oluşturduğu veri yapısının faktör analizi için uygun olup olmadığını tespit etmek için kullanılmaktadır. Barlett Küresellik testi korelasyon matrisindeki ilişkilerin faktör analizi yapacak düzeyde olup olmadığını göstermektedir.

Tablo 3. Ölçeklere ilişkin KMO ve Barlett's küresellik testi sonuçları

\begin{tabular}{|c|c|c|c|}
\hline & $\begin{array}{c}\text { Sanal Kaytarma } \\
\text { Ölçeği }\end{array}$ & $\begin{array}{c}\text { İ̀gören Performans1 } \\
\text { Ölçeği }\end{array}$ & $\begin{array}{l}\text { İş Stresi } \\
\text { Ölçeği }\end{array}$ \\
\hline $\begin{array}{lcc}\text { Örneklem } & \text { Yeterliliğine } & \text { Yönelik } \\
\text { Kaiser-Mever-Olkin (KMO) Değeri }\end{array}$ & 916 & 859 & 869 \\
\hline Yaklaşı Ki-Kare Değeri & 3408,018 & 1215,438 & 1288,736 \\
\hline Serbestlik Derecesi (Df) & 78 & 6 & 21 \\
\hline Anlamlılık (Sig.) & ,000 & ,000 &, 000 \\
\hline
\end{tabular}

KMO değerinin 0,60 ve üstünde olması örneklemin faktör analizi için uygun olduğu anlamına gelmektedir (Gürbüz ve Şahin, 2016, s. 311). Bu kapsamda Tablo 3'te görüldüğü üzere Kaiser-Meyer-Olkin örneklem yeterliliği değerinin (KMO), sanal kaytarma ölçeği için 0,916 , işgören performans1 ölçeği için 0,859 , ve iş stresi ölçeği için 0,869 bulunması örneklemin faktör analizi için uygun olduğunu göstermektedir. Barlett's Küresellik testi sonucunun anlamlı olması $(p<0,05)$ değişkenler arası ilişkilerin oluşturduğu matrisin faktör analizi için uygun olduğu anlamına gelmektedir. Tablo 3'te görüldügüü gibi Barlett's Küresellik Testi sonuçlarının sanal kaytarma ölçeği için Sig. $=0.0000$, işgören performansı ölçeği için Sig. $=0.0000$, ve iş stresi ölçeği için Sig. $=0.0000$ bulunması, değişkenler arası ilişkilerin oluşturduğu matrisin faktör analizi için anlamlı olduğunu göstermektedir. Kaiser-Meyer-Olkin (KMO) ve Bartlett's Küresellik Testleri sonucunda, araştırmada kullanılan her üç ölçeğinde faktör analizi için uygun olduğu görülmektedir.

\subsection{Faktör Analizine İlişkin Bulgular}

Araştırmada kullanılan ölçeklerin yapı geçerliliği keşfedici faktör analizi (KFA) ile test edilmiştir. Faktör analizi, birbiriyle ilişkili çok sayıdaki maddenin bir araya getirilerek, birbiri ile tutarlı daha az sayıda faktör elde etmeyi amaçlayan, çok değişkenli analizlerin genel adıdır (Gürbüz ve Şahin, 2016, s. 309).

Keşfedici faktör analizinin ölçeklere uygulanmasında temel bileşenler (principal component) analizi ve "varimaks" eksen döndürmesi tekniği kullanılmıştır. Faktör oluşması için, öz değerlerin (eigen values) 1'den büyük olması, maddelerin ilgili faktörde en az 0,40 düzeyinde yük değerine sahip olması, bir faktörün en az üç maddeden oluşması esas alınmıştır. 


\subsubsection{Sanal Kaytarma Ölçeğine İlişkin Faktör Analizi Bulguları}

Sanal kaytarma ölçeğine uygulanan faktör analizi sonucunda, ölçek ifadelerinin ölçeğin aslında olduğu gibi iki faktörde toplandığı tespit edilmiştir. Belirlenen bu faktörler İnternette Gezinme Faaliyetleri (Browsing) ve E-posta Faaliyetleri (E-mailing) olarak adlandırılmıştır. İki faktör toplam varyansın \%62,425'ini açıklamaktadır. Sanal kaytarma ölçeğine ilişkin faktör analizi bulguları Tablo 4'te sunulmuştur.

Tablo 4. Sanal kaytarma ölçeğine ilişkin faktör analizi bulguları

\begin{tabular}{|c|c|c|}
\hline Madde & $\begin{array}{l}\text { İnternette } \\
\text { Gezinme } \\
\text { Faaliyetleri } \\
\text { (Bowsing) }\end{array}$ & $\begin{array}{c}\text { E-posta } \\
\text { Faaliyetleri } \\
\text { (E-mailing) }\end{array}$ \\
\hline 1. Mesai saatlerinde eğlence amaçlı internet sitelerini ziyaret ederim. & ,805 & \\
\hline 2. Mesai saatlerinde işle ilgisi olmayan internet sitelerini ziyaret ederim. & ,802 & \\
\hline 3. Mesai saatlerinde genel haber amaçlı internet sitelerini ziyaret ederim. & ,724 & \\
\hline 4. Mesai saatlerinde sporla ilgili internet sitelerini ziyaret ederim. & 666 & \\
\hline 5. Mesai saatlerinde işle ilgisi olmayan bilgileri, internet üzerinden indiririm. & 618 & \\
\hline 6. Mesai saatlerinde iş aramak için interneti kullanırım. &, 542 & \\
\hline 7. Mesai saatlerinde çevrimiçi (online) mesaj gönderirim. &, 531 & \\
\hline 8. Mesai saatlerinde çevrimiçi (online) alışveriş yaparım. &, 524 & \\
\hline 9. Mesai saatlerinde çevrimiçi (online) oyun oynarım & ,482 & \\
\hline 10. Mesai saatlerinde yetişkin odaklı internet sitelerini ziyaret ederim. & 450 & \\
\hline 11. Mesai saatleri içinde işle ilgili olmayan e-postalara bakarım. & & ,881 \\
\hline 12. Mesai saatleri içinde işle ilgili olmayan e-posta gönderirim. & & ,878 \\
\hline 13. Mesai saatleri içinde işle ilgili olmayan e-posta alırım. & &, 854 \\
\hline Özdeğerler (Eigenvalues) & 7,005 & 1,111 \\
\hline Açıklanan Varyans Yüzdesi \% & 53,882 & 8,543 \\
\hline Toplam Açılanan Varyans Yüzdesi \% & \multicolumn{2}{|c|}{62,425} \\
\hline
\end{tabular}

Not: 0.4 'ten küçük faktör yükleri tabloda gösterilmemiştir.

\subsection{2. İşgören Performansı Ölçeğine İlişkin Faktör Analizi Bulguları}

İşgören performansı ölçeğine uygulanan faktör analizi sonucunda, ölçeğin aslında olduğu gibi tek faktör elde edilmiştir. Bu faktör toplam varyansın \%81,400'ünü açılamaktadır. İşgören performansı ölçeğine ilişkin faktör analizi bulguları Tablo 5'te sunulmuştur.

Tablo 5. İşgören performansı ölçeğine ilişkin faktör analizi bulguları

\begin{tabular}{lc}
\hline \multicolumn{1}{c}{ Madde } & İşören Performans1 \\
\hline 1. Görevlerimi tam zamanında tamamlarım. &, 918 \\
2. İş hedeflerime fazlasıyla ulaşırım. &, 909 \\
3. Sunduğum hizmet kalitesinde standartlara fazlasıyla ulaştığımdan &, 908 \\
4. Bir problem gündeme geldiğinde en hızlı şekilde çözüm üretirim. &, 874 \\
Özdeğerler (Eigenvalues) & 3,256 \\
Açıklanan Varyans Yüzdesi \% & 81,400 \\
Toplam Açıklanan Varyans Yüzdesi \% & 81,400 \\
\hline
\end{tabular}

Not: 0.4 'ten küçük faktör yükleri tabloda gösterilmemiştir.

\subsection{3. İş Stresi Ölçeğine İlişkin Faktör Analizi Bulguları}

İş stresi ölçeğine uygulanan faktör analizi sonucunda, ölçeğin aslında olduğu gibi tek faktör elde edilmiştir. Bu faktör toplam varyansın \%56,979'unu açıklamaktadır. İş stresi ölçeğine ilişkin faktör analizi bulguları Tablo 6'da sunulmuştur. 
Tablo 6. İş stresi ölçeğine ilişkin faktör analizi bulguları

\begin{tabular}{lc}
\hline \multicolumn{1}{c}{ Madde } & İş Stresi \\
\hline 1.İşimden dolayı kendimi asabi hissediyorum. &, 850 \\
2. Farklı bir işte çalışıyor olsam sağlığım muhtemelen daha iyi olur. &, 820 \\
3. Oldukça büyük bir gerilim altında çalışıyorum. &, 810 \\
4.İşimle ilgili sorunlar uyku sorunu yaşamama neden oluyor. &, 772 \\
5.İşim sağlığımı doğrudan etkilemeye yatkındır. &, 762 \\
6.İşyerimde düzenlenen toplantılar öncesi kendimi gergin hissediyorum. &, 712 \\
7. Evde olduğum zamanlar başka işler yappıor olsam da sıklıkla işimle ilgili konuları &, 504 \\
düşünüyorum. & 3,989 \\
Özdeğerler (Eigenvalues) & 56,979 \\
Açıklanan Varyans Yüzdesi \% & 56,979 \\
Toplam Açılanan Varyans Yüzdesi \%
\end{tabular}

Not: 0.4 'ten küçük faktör yükleri tabloda gösterilmemiştir.

Tabachnick ve Fidell (2001) keşfedici faktör analizinde, tüm faktörlerin açıkladıkları toplam varyansın, tek boyutlu ölçeklerde en az \%30, çok boyutlu ölçeklerde ise en az \%50 olması gerektiğini belirtmektedirler. Bu kapsamda araştırmada kullanılan sanal kaytarma ölçeği $(\% 62,42)$, işgören performansı ölçeği $(\% 81,40)$ ve iş stresi ölçeğine $(\% 56,97)$ ait faktörlerin açıkladıkları toplam varyanslar \%50'nin üzerinde olduğu tespit edilmiştir.

\subsection{Normallik Testi}

Araştırma kapsamında elde edilen verilere uygulanacak istatistiksel analizlerin belirlenmesi için önce verilerin normal dağılıp dağ 1 lmadığ tespit edilmeye çalışılmıştır. Korelasyon ve regresyon analizi gibi parametrik testlerin uygulanabilmesi için sağlanmasi gereken varsayımlardan biri verilerin normal dağılması koşuludur (Akar, 2018, s. 227). Bu kapsamda "Sanal Kaytarma Ölçeği", "İşgören Performansı Ölçeği”" ve "İş stresi Ölçeği” ile elde edilen veriler normallik testine tabi tutulmuştur. Normallik Testi Sonuçları Tablo 7'de sunulmuştur.

Tablo 7. Normallik testi sonuçları

\begin{tabular}{lcc}
\hline & Çarpıklık (Skewness) & Basıklık (Kurtosis) \\
\hline Sanal Kaytarma &, 471 &,- 565 \\
İşgören Performansı &,- 951 &, 201 \\
İş Stresi &,- 354 &,- 696 \\
\hline
\end{tabular}

Tabachnick ve Fidell'e (2001) göre Çarpıklık (Skewness) ve Basıklık (Kurtosis) değerlerinin $+1,5$ ile $-1,5$ arasında bir değerde olması, verilerin normal dağılım gösterdiğini ifade etmektedir. George ve Mallery'e (2010) göre ise bu değerlerin $+2,0$ ile $-2,0$ aralığında bulunması durumunda da verilerin normal dağ 1 lım gösterdiği söylenebilir. Tablo 7'de görüldüğü gibi her 3 ölçek verisi için Çarpıklık (Skewness) ve Basıklık (Kurtosis) değerlerinin +1,5 ile 1.5 aralığında olduğu ve normal dağılım gösterdiği tespit edilmiştir. Sonuç olarak değişkenler arasında korelasyon ve regresyon gibi parametrik testler uygulanabilir.

\subsection{Korelasyon Analizi Sonuçları}

Araştırma değişkenleri arasında anlamlı bir ilişkinin var olup olmadığını anlamak için çoklu korelasyon analizi yapılmıştır. Pearson korelasyon analizine ait sonuçlar Tablo 8'de sunulmuştur. 
Tablo 8. Değişkenler arasındaki çoklu korelasyon analizi

\begin{tabular}{|c|c|c|c|c|c|}
\hline Değișkenler & 1 & 2 & 3 & 4 & 5 \\
\hline 1. Sanal Kaytarma & 1 & & & & \\
\hline 2. İnternette Gezinme Faaliyetleri & $975 * *$ & 1 & & & \\
\hline 3. E-posta Faaliyetleri &, $848 * *$ &, $710 * *$ & 1 & & \\
\hline 4. İşgören Performansı &,$- 625 * *$ &,$- 622 * *$ &,$- 500 * *$ & 1 & \\
\hline 5. İş Stresi &, $312 * *$ &, $344 * *$ &, $168 * *$ &,$- 379 * *$ & 1 \\
\hline
\end{tabular}

Analiz sonuçlarına göre sanal kaytarma ile işgören performansı arasında anlamlı ve negatif yönlü bir ilişki olduğu tespit edilmiştir $(r=-0,62, p<0.01)$. Sanal kaytarma ile iş stresi arasında ise anlamlı ve pozitif yönlü bir ilişki olduğu tespit edilmiştir $(r=0,31, \mathrm{p}<0.01)$. Sanal kaytarmanın alt boyutlarından internette gezinme faaliyetlerinin, işgören performansı ile arasında anlamlı ve negatif yönlü bir ilişsi $(\mathrm{r}=-0,62, \mathrm{p}<0.01)$, iş stresi ile ise anlamlı ve pozitif yönlü bir ilişkisi olduğu tespit edilmiştir $(\mathrm{r}=0,34, \mathrm{p}<0.01)$. Sanal kaytarmanın bir diğer alt boyutu olan e-posta faaliyetlerinin, işgören performansı ile arasında anlamlı ve negatif yönlü bir ilişki $(r=-0,50, p<0.01)$, iş stresi ile ise anlamlı ve pozitif yönlü bir ilişkisi olduğu tespit edilmiştir $(\mathrm{r}=0,16, \mathrm{p}<0.01)$. İ̧gören performansı ile iş stresi arasında anlamlı ve negatif yönlü bir ilişki $(\mathrm{r}=-0,37, \mathrm{p}<0.01)$ olduğu tespit edilmiştir.

Değişkenler arasındaki pozitif yönlü (olumlu) bir ilişki, iki değişkenin birlikte değiş̧iğini, negatif yönlü (olumsuz) bir ilişki ise, değişkenlerden biri artarken diğerinin azaldığını göstermektedir (Gürbüz ve Şahin, 2016, s. 267).

\subsection{Basit Doğrusal Regresyon Analizi Sonuçları}

Bağımsız değişkenin, bağımlı değişken üzerindeki etkisinin anlamlı olup olmadığını ve önem derecesini belirlemek için regresyon analizi kullanılmaktadır. Basit doğrusal regresyon analizinde, bağımlı değiş̧keni etkileyen tek bir bağımsız değişken bulunmaktadır. Bu kapsamda, tek boyuttan oluşan iş stresi ile işgören performansı arasındaki ilişkinin incelenmesinde basit doğrusal regresyon analizi kullanılmıştır.

Araştırmanın ilk hipotezi olan "H1: $\dot{I}_{S ̧}$ stresinin işgören performansı üzerinde anlamlı ve negatif yönde etkisi vardır." hipotezine ilişkin basit doğrusal regresyon analizi sonuçları Tablo 9'da sunulmuştur.

Tablo 9. İş stresi ve işgören performansı ilişkisine yönelik regresyon analizi sonuçları

\begin{tabular}{cccccc}
\hline $\mathrm{R}$ & $\mathrm{R}^{2}$ & Düzeltilmiş $\mathrm{R}^{2}$ & $\mathrm{~F}$ & $\beta$ & $\begin{array}{c}\text { Anlamlılık } \\
\text { (ANOVA) }\end{array}$ \\
\hline 0,379 & 0,143 & 0,141 & 66,924 &,- 379 & 0,000 \\
\hline
\end{tabular}

Bağımlı Değiş̧ken: İşgören Performansı, Bağımsız Değişken: İş Stresi

Tablo 9'daki regresyon analizi sonuçlarına göre iş stresinin, işgören performansı üzerinde anlamlı ve negatif bir etkiye sahip olduğu görülmektedir $(\beta=-, 379 p<0.001)$. Düzeltilmiş $\mathrm{R}^{2}$ değeri 0.14 olması, işgören performansıdaki \%14'lük varyansın iş stresine bağlı olduğunu göstermektedir. Sonuç olarak H1 hipotezi kabul edilmiştir.

\section{8. Çoklu Regresyon Analizi Sonuçları}

Çoklu regresyon analizi, bir bağımlı değişkenin üzerinde birden fazla bağımsız değişkenin etkisini incelemek için kullanılmaktadır. Bu kapsamda, araştırmada öne sürülen $\mathrm{H} 2$, $\mathrm{H} 2 \mathrm{a}, \mathrm{H} 2 \mathrm{~b}, \mathrm{H} 3, \mathrm{H} 3 \mathrm{a}$ ve $\mathrm{H} 3 \mathrm{~b}$ hipotezlerinin test edilmesinde çoklu regresyon analizi kullanılmıştır. Sanal kaytarmanın alt boyutları ile işgören performansı arasındaki ilişkiye yönelik çoklu regresyon analizi sonuçları Tablo 10'da sunulmuştur. 
Tablo 10. Sanal kaytarma ve işgören performansı ilişkisine yönelik çoklu regresyon analizi sonuçları

\begin{tabular}{|c|c|c|c|c|c|c|c|c|}
\hline $\begin{array}{l}\text { Bağımlı } \\
\text { Değişken }\end{array}$ & Bağımsız Değişken & B & $\begin{array}{c}\text { S. } \\
\text { Hata }\end{array}$ & Beta & $\mathrm{t}$ & $\mathrm{p}$ & Tolerans & VIF \\
\hline \multirow{2}{*}{$\begin{array}{l}\text { İşgören } \\
\text { Performans1 }\end{array}$} & $\begin{array}{l}\text { İnternette Gezinme } \\
\text { Faaliyetleri }\end{array}$ &,- 596 & ,061 &,- 537 & $-9,706$ & 000 & ,565 & 1,771 \\
\hline & E-posta Faaliyetleri &,- 094 & ,044 &,- 119 & $-2,145$ & ,033 &, 571 & 1,750 \\
\hline
\end{tabular}

Tablo 10'daki çoklu regresyon analizi sonuçlarına göre oluşturulan model istatistiksel olarak anlamlıdır ( $\mathrm{p}<0.001$ ). Düzeltilmiş $\mathrm{R}^{2}$ değeri 0,39 'dur. $\mathrm{Bu}$ sonuç işgören performansındaki \%39 oranındaki varyansın internette gezinme faaliyetleri ve e-posta faaliyetleri tarafından açıklandığını göstermektedir. Tablodaki Beta katsayıları incelendiğinde, işgören performansını açıklamada internette gezinme faaliyetlerinin $(\beta=-, 537 \mathrm{p}<0.01)$ ve eposta faaliyetlerinin $(\beta=-, 119 \mathrm{p}<0.05)$ anlamlı ve negatif bir etkiye sahip olduğu görülmektedir. Ayrıca modelde çoklu eş doğrusallık problemi olup olmadığını tespit etmek için tolerans ve VIF değerleri incelenmiştir. Bu değerler bağımsız değişkenler arasında çoklu eş doğrusallık problemi olmadığını (Tolerans> .2; VIF < 10) göstermiştir. Sonuç olarak H2, H2a ve H2b hipotezleri kabul edilmiştir.

Sanal kaytarmanın alt boyutları ile iş stresi arasındaki ilişkiye yönelik çoklu regresyon analizi sonuçları Tablo 11'de sunulmuştur.

Tablo 11. Sanal kaytarma ve iş stresi ilişkisine yönelik çoklu regresyon analizi sonuçları

\begin{tabular}{llccccccc}
\hline $\begin{array}{l}\text { Bağımlı } \\
\text { Değişken }\end{array}$ & Bağımsız Değişken & $\mathrm{B}$ & $\begin{array}{c}\mathrm{S} . \\
\text { Hata }\end{array}$ & Beta & $\mathrm{t}$ & $\mathrm{p}$ & \multirow{2}{*}{ Tolerans } & \multirow{2}{*}{ VIF } \\
\hline \multirow{2}{*}{ Is Stresi } & İnternette Gezinme &, 461 &, 067 &, 454 & 6,844 &, 000 &, 496 & 2,015 \\
& Faaliyetleri & & & & & & & \\
\cline { 2 - 8 } & E-posta Faaliyetleri &,- 112 &, 048 &,- 154 & $-2,318$ &, 021 &, 496 & 2,015 \\
\hline $\mathrm{F}=29,914$ & $\mathrm{R}^{2}=, 13$ Düzeltilmiş $\mathrm{R}^{2}=, 12$ & Tah.Stnd. Hata $=, 86099$ Anlamlılık (ANOVA) $=, 000$ &
\end{tabular}

Tablo 11'deki çoklu regresyon analizi sonuçlarına göre oluşturulan model istatistiksel olarak anlamlıdır ( $\mathrm{p}<0.001$ ). Düzeltilmiş $\mathrm{R}^{2}$ değeri 0,12 'dir. Bu sonuç iş stresindeki $\% 12$ oranındaki varyansın internette gezinme faaliyetleri ve e-posta faaliyetleri tarafindan açıklandığını göstermektedir. Tablodaki Beta katsayıları incelendiğinde, iş stresini açıklamada internette gezinme faaliyetlerinin $(\beta=, 454 \mathrm{p}<0.01)$ pozitif ve anlamlı ve e-posta faaliyetlerinin $(\beta=-, 154 \mathrm{p}<0.05)$ ise negatif ve anlamlı bir etkiye sahip olduğu görülmektedir. Ayrıca modelde çoklu eş doğrusallık problemi olup olmadığını tespit etmek için tolerans ve VIF değerleri incelenmiştir. $\mathrm{Bu}$ değerler bağımsız değişkenler arasında çoklu eş doğrusallık problemi olmadığını (Tolerans> .2; VIF < 10) göstermiştir. Sonuç olarak "H3 ve H3a hipotezleri kabul edilmiş, H3b hipotezi reddedilmiştir.

\subsection{Düzenleyicilik Etkisinin Belirlenmesine Yönelik Regresyon Analizi}

Düzenleyici değişken (moderatör) bağımlı değişken ile bağımsız değişken arasındaki ilişkinin yönünü ve şiddetini etkileyen niceliksel ya da niteliksel bir değişkendir (Gürbüz ve Şahin, 2016, s. 298). Genel olarak moderatör (düzenleyici) analizinin yapılmasında üç yöntemden birisi kullanılmaktadır: regresyon temelli analiz, yapısal eşitlik modellemesi temelli analiz ve ANOVA temelli analiz (Sakalli, 2015, s. 110). Bu araştırmada regresyon temelli analiz yöntemi kullanılmıştır. Analizlerde Andrew F. Hayes (2013) tarafindan geliştirilen Process sürüm 3.2 isimli SPSS eklentisi kullanılmıştır. Process eklentisi 74 farklı mediation (arac1) ve moderatör (düzenleyici) modelini regresyon temelli analizler kullanarak test etmeyi mümkün kılmaktadır. Bu kapsamda, araştırmada öne sürülen H4, H5 ve H6 hipotezleri Process eklentisi kullanılarak test edilmiştir. 
Düzenleyici modelin testi için öncelikle etkileşimsel terimin oluşturulması gerekmektedir. Bu işlem standardize edilmiş bağımsız değişken (X) ve düzenleyici değişkenin (M) çarpılmasıyla yapılır. Regresyon modeline dâhil edilen etkileşimsel terim istatiksel olarak anlamlı ise ve bağımlı değişkendeki (Y) varyansı açıklamada katkıda bulunuyorsa, düzenleyicilik etkisi ortaya çıkmış demektir (Gürbüz ve Şahin, 2016, s. 295). H4 hipotezine ilişkin analiz sonuçları Tablo 12.'de sunulmuştur.

Tablo 12. Hipotez 4 'e ilişkin analiz sonuçları

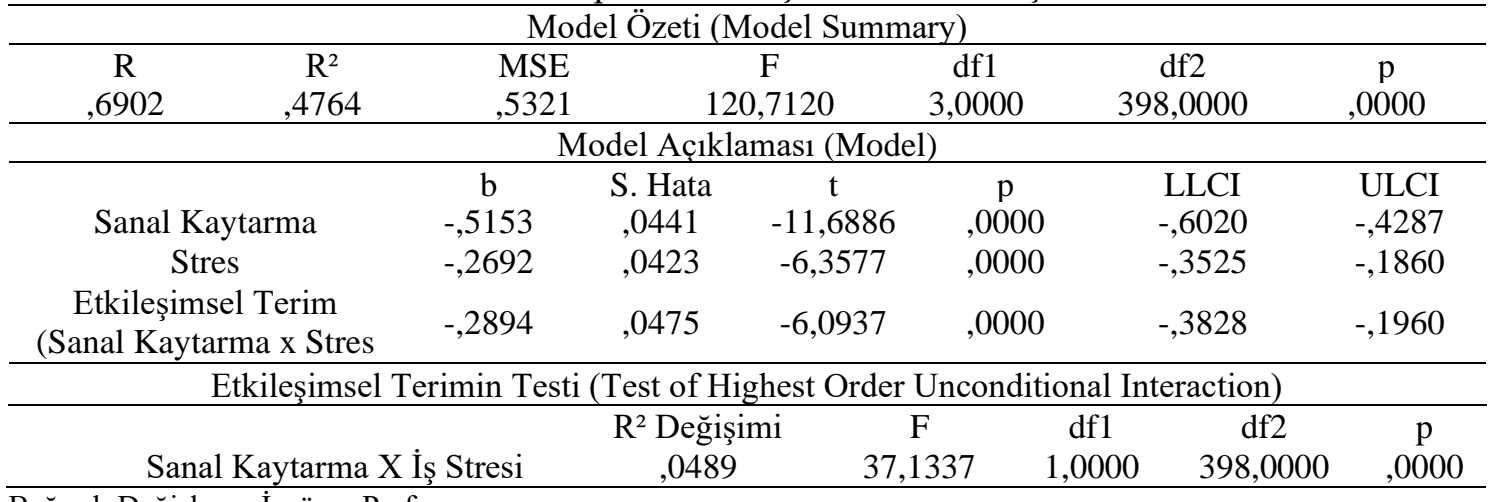

Bağımlı Değişken= İşgören Performansı

**LLCI (Lower-limit of confidence interval), ULCI (Upper-limit of confidence interval)

Tablo 12'deki analiz sonuçlarına göre; Genel model istatistiksel olarak anlamlıdır; F $(3,398)=120.71, \mathrm{p}<.001, \mathrm{R}^{2}=.48 . \mathrm{R}^{2}$ değerinin 0,48 olması, işgören performansındaki $\% 48$ (\%5 Etkileşimsel Terim) gibi önemli bir oranındaki varyansın sanal kaytarma, iş stresi ve bu iki değişkenin etkileşimi tarafindan açıklandığını göstermektedir. Sanal kaytarma değişkeni işgören performansı üzerinde önemli ve negatif bir etkiye sahiptir; $b=-, 51, t(398)=-11,68, p=.000$. İş stresi değişkeni işgören performansı üzerinde önemli ve negatif bir etkiye sahiptir; $b=-, 27, t$ $(398)=-6,35, p=.000$. Etkileşimsel terim işgören performansı üzerinde önemli ve negatif bir etkiye sahiptir; $\mathrm{b}=-, 29, \mathrm{t}(398)=-6,09, \mathrm{p}=.000 . \mathrm{R}^{2}$ Değişim değerinin, 05 olduğu görülmektedir. $\mathrm{Bu}$ oran etkileşimsel terimin işgören performansında $\% 5$ 'lik ilave varyansa neden olduğunu göstermektedir. Yani genel modelin açıkladığ1 \%48'lik varyansın, \%5'ini etkileşimsel terim oluşturmaktadır. $\mathrm{R}^{2}$ deki bu değişim anlamlı bulunmuştur; $\mathrm{F}(1,398)=37,13$, $\mathrm{p}=.000$. Bu sonuçlara göre, sanal kaytarma ile işgören performansı arasındaki ilişkinin iş stresi tarafından düzenlendiği (moderatör etki) anlaşılmaktadır. Bu kapsamda H4 hipotezi kabul edilmiştir. H5 hipotezine iliş̧in analiz sonuçları Tablo 13'te sunulmuştur.

Tablo 13. Hipotez 5 'e ilişskin analiz sonuçları

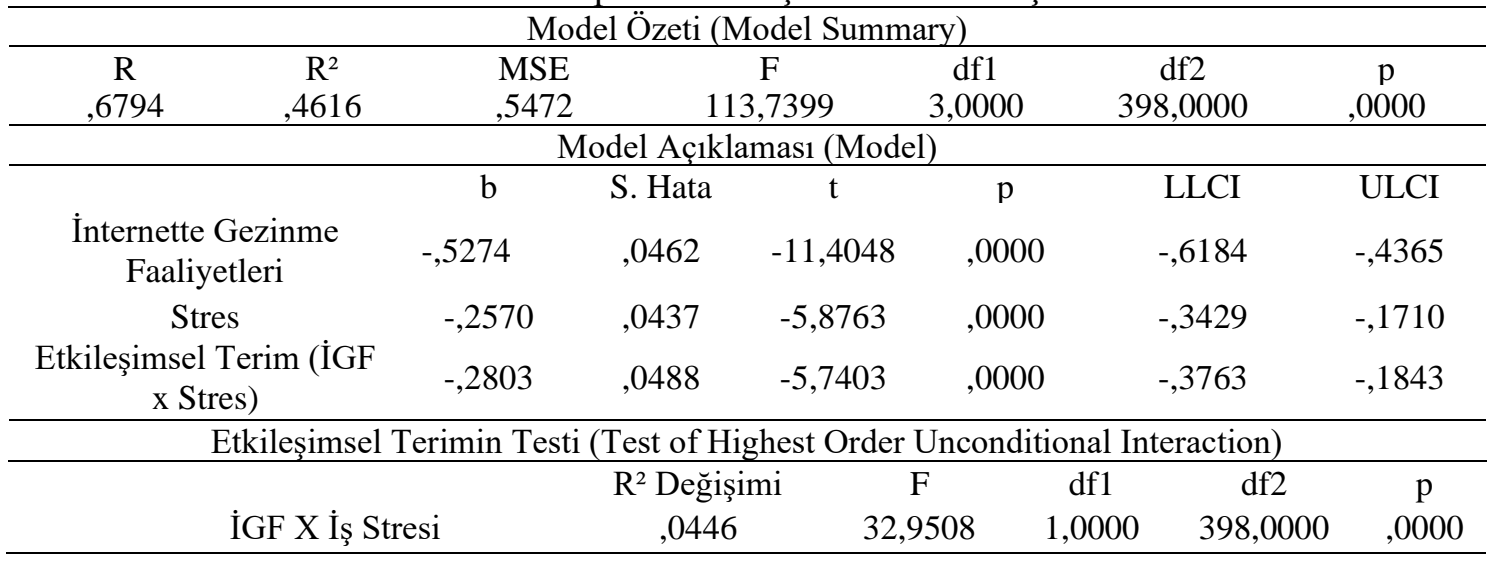

Tablo 13'teki analiz sonuçlarına göre; Genel model istatistiksel olarak anlamlıdır; $F$ $(3,398)=113.73, \mathrm{p}<.001, \mathrm{R}^{2}=.46 . \mathrm{R}^{2}$ değerinin 0,46 olmas1, işgören performansındaki \%46 (\%4 Etkileşimsel Terim) gibi önemli bir oranındaki varyansın internette gezinme faaliyetleri, iş stresi ve bu iki değişkenin etkileşimi tarafından açıklandığını göstermektedir. İnternette gezinme 
faaliyetleri değişkeni işgören performansı üzerinde önemli ve negatif bir etkiye sahiptir; $b=$ $, 52, \mathrm{t}(398)=-11,40, \mathrm{p}=.000$. İş stresi değişkeni işgören performansı üzerinde önemli ve negatif bir etkiye sahiptir; $\mathrm{b}=-, 26, \mathrm{t}(398)=-5,87, \mathrm{p}=.000$. Etkileşimsel terim işgören performansı üzerinde önemli ve negatif bir etkiye sahiptir; $b=-, 28, t(398)=-5,74, p=.000 . R^{2}$ Değişim değerinin ,04 olduğu görülmektedir. $\mathrm{Bu}$ oran etkileşimsel terimin işgören performansında \%4'lük ilave varyansa neden olduğunu göstermektedir. Yani genel modelin açıkladığı \%46'lık varyansın, \%4'ünü etkileşimsel terim oluşturmaktadır. $\mathrm{R}^{2}$ deki bu değişim anlamlı bulunmuştur; $\mathrm{F}(1,398)=32,95, \mathrm{p}=.000$. Bu sonuçlara göre, internette gezinme faaliyetleri ile işgören performansı arasındaki ilişkinin iş stresi tarafından düzenlendiği (moderatör etki) anlaşılmaktadır. Bu kapsamda H5 hipotezi kabul edilmiştir.

"H6: Sanal kaytarma davranışlarının alt boyutu olan e-posta faaliyetleri ile işgören performansı ilişkisi üzerinde, iş stresinin düzenleyici etkisi vardır." hipotezine ilişkin analiz sonuçları Tablo 14'te sunulmuştur.

Tablo 14. Hipotez 6 'ya ilişkin analiz sonuçları

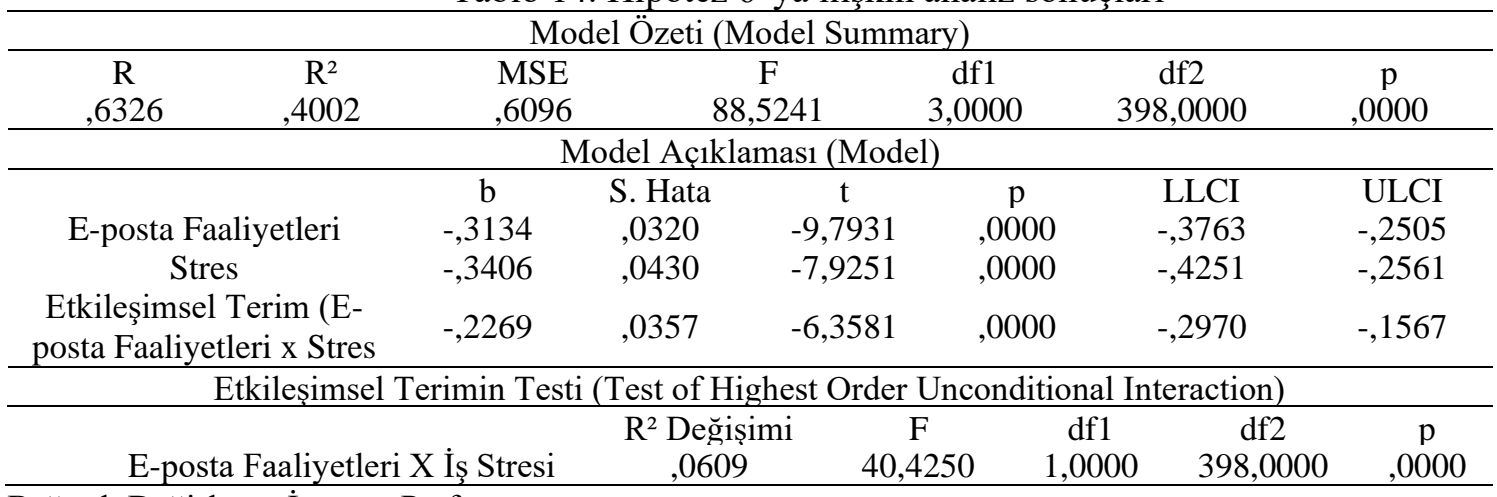

Bağımlı Değişken= İşgören Performansı

**LLCI (Lower-limit of confidence interval), ULCI (Upper-limit of confidence interval)

Tablo 14'deki analiz sonuçlarına göre; Genel model istatistiksel olarak anlamlıdır; F $(3,398)=88.52, \mathrm{p}<.001, \mathrm{R}^{2}=.40 . \mathrm{R}^{2}$ değerinin 0,40 olması, işgören performansındaki $\% 40$ (\%6 Etkileşimsel Terim) gibi önemli bir oranındaki varyansın e-posta faaliyetleri, iş stresi ve bu iki değişkenin etkileşimi tarafından açıklandığını göstermektedir. E-posta faaliyetleri değişkeni işgören performansı üzerinde önemli ve negatif bir etkiye sahiptir; b = -,31, t (398) = $9,79, \mathrm{p}=.000$. İş stresi değişkeni işgören performansı üzerinde önemli ve negatif bir etkiye sahiptir; $\mathrm{b}=-, 34, \mathrm{t}(398)=-7,92, \mathrm{p}=.000$. Etkileşimsel terim işgören performansı üzerinde önemli ve negatif bir etkiye sahiptir; $b=-, 22, t(398)=-6,35, p=.000 . R^{2}$ Değişim değerinin ,06 olduğu görülmektedir. $\mathrm{Bu}$ oran etkileşimsel terimin işgören performansında \% $\% 6^{\prime}$ lık ilave varyansa neden olduğunu göstermektedir. Yani genel modelin açıkladığ $1 \% 40$ 'lık varyansın, \%6'sını etkileşimsel terim oluşturmaktadır. $\mathrm{R}^{2}$ deki bu değişim anlamlı bulunmuştur; F $(1,398)$ $=40,42, \mathrm{p}=.000 \mathrm{.} \mathrm{Bu}$ sonuçlara göre, e-posta faaliyetleri ile işgören performansı arasındaki ilişkinin iş stresi tarafindan düzenlendiği (moderatör etki) anlaşılmaktadır. Bu kapsamda H6 hipotezi kabul edilmiştir.

\section{Sonuç, Tartışma ve Öneriler}

Literatürde sanal kaytarma, işgören performansı ve iş stresi farklı değişkenlerle ya da birbirleriyle araştırma konusu yapılmıştır. Ancak, Türkçe ve İngilizce literatür taraması sonucunda sanal kaytarma, işgören performansı ve iş stresi değişkenleri arasındaki ilişkiyi inceleyen bir araştırmaya rastlanmamıştır. $\mathrm{Bu}$ nedenle araştırmanın sonuçlarının literatüre önemli bir katkı sağlayacağı öngörülmektedir.

Araştırma verileri sağlık sektöründe görevli işgörenlerden elde edilmiştir. Sağlık sektörünün ülke bütçesindeki yeri, bu alanda yapılan yatırımlar ve en önemlisi insan hayatı üzerindeki etkisi ve önemi, araştırmada bu sektörün seçilmesinin başlıca nedenleridir. Bu 
sektörün en önemli unsuru olan sağlık çalışanlarının, performansını etkileyen unsurların belirlenmesi, kamu ve özel sağlık kurumlarında görevli yöneticilere, karar verme süreçlerinde olumlu katkılar sağlayacağı düşünülmektedir.

$\mathrm{Bu}$ araştırmada, sağlık çalışanlarının sanal kaytarma davranışları ile performansları arasındaki ilişki ve bu ilişki üzerinde iş stresinin düzenleyici etkisi incelenmiştir. Yapılan analizler sonucunda, sanal kaytarmanın, işgören performansı üzerinde anlamlı ve negatif bir etkiye sahip olduğu tespit edilmiştir. Araştırmanın bu bulgusu, Bock ve Ho (2009); Afacan Findıklı (2016); Bilgin Demir, Ürek ve Uğurluoğlu (2017); Santos'un (2016) yaptıkları çalışmalarla aynı doğrultudadır. Araştırma kapsamında sanal kaytarmanın alt boyutları olarak kabul edilen, internetten gezinme faaliyetleri ile e-posta faaliyetlerinin, işgören performansı üzerinde anlamlı ve negatif bir etkiye sahip olduğu tespit edilmiştir. Araştırmanın bir diğer değişkeni olan iş stresinin, işgören performansı üzerinde anlamlı ve negatif bir etkisi olduğu tespit edilmiştir. Araştırmanın bu bulgusu, Alkan (2014); Shahid vd.'nin (2011) yaptıkları çalışmalarla aynı doğrultudadır. Sanal kaytarma değişkeni ile iş stresi arasındaki ilişkinin analizi sonucunda, sanal kaytarmanın alt boyutlarından internette gezinme faaliyetlerinin iş stresi üzerinde anlamlı ve pozitif bir etkiye sahip olduğu, bir diğer alt boyut olan e-posta faaliyetlerinin ise iş stresi üzerinde anlamlı ve negatif bir etkiye sahip olduğu tespit edilmiştir.

Araştırmanın temel amacı olan iş stresinin düzenleyici etkisini belirlemeye yönelik yapılan analizler sonucunda, sanal kaytarma ve işgören performansı ilişkisi üzerinde, iş stresinin düzenleyici etkisi olduğu ve sanal kaytarmanın işgören performansı üzerindeki etkisinin, yüksek iş stresine sahip işgörenlerde, düşük iş stresine sahip işgörenlere göre daha yüksek olduğu tespit edilmiştir.

Çalı̧̧ma sonucunda sanal kaytarmanın, işgören performansını anlamlı derecede ve negatif yönde etkilediği tespit edilmiştir. Ayrıca bu etkide iş stresinin, sanal kaytarmanın performans üzerindeki etkisini arttırarak düzenleyici bir role sahip olduğu ve sanal kaytarmanın işgören performansı üzerindeki etkisinin, yüksek iş stresine sahip işgörenlerde, düşük iş stresine sahip işgörenlere göre daha yüksek olduğu tespit edilmiştir. Bu bulgulardan yola çıkarak yöneticilere ve araştırmacılara şu önerilerde bulunulabilir.

Sanal kaytarma davranışlarının, işgören performansı üzerindeki negatif ve anlamlı bir etkiye sahip olması nedeniyle, yöneticilerin bu davranışları kontrol etmesi işgören performansının yükselmesini sağlayabilir. İşgörenlerin sanal kaytarma davranışlarının kontrol edilmesinde, çalışanların periyodik olarak izlenmesi (Blanchard ve Henle, 2008) ve internet kullanımına ilişkin önemli kısıtlamalar (Garrett ve Danziger, 2008, s. 946) etkili bir yöntem olarak görülmektedir. Bu kapsamda, örgüt internet kullanım politikalarının gözden geçirilerek, gerekli düzeltmelerin yapılması tavsiye edilebilir. Sanal kaytarma davranışlarının kontrol edilmesinde çalışanların cezalandırılmasının ise etkili bir yol olmadığı belirtilmektedir (Liao vd., 2009, s. 49). Ayrıca yöneticilerin, çalışanlara olan fiziksel yakınlığı, çalışanların algıladığı örgütsel kontrolü arttırmakta ve sonuç olarak sanal kaytarma davranışları azalmaktadır.

Sanal kaytarma davranışlarının işgören performansı üzerindeki etkisini, iş stresinin daha da arttırması nedeniyle, yöneticilerin çalışanlarda strese neden olan etmenleri belirleyerek, gerekli önlemleri alması iş stresinin azalmasını, işgören performansının artmasını sağlayabilir. Rol belirsizliği, rol çatışması, mesleki belirsizlikler ve aşırı iş yükü veya az çalışma iş stresine neden olan örgütsel faktörlerdir. Gürültü, aydınlatma, ısınma ve havalandırma iş stresine neden olan fiziksel faktörler olarak görülürken, çalışanın kişilik özellikleri bireysel faktörler olarak görülmektedir (Şimşek, Akgemci ve Çelik, 2008, s. 337). Stresi etkileyen bu faktörler göz önüne alındığında yöneticilere bazı önerilerde bulunulabilir. Yöneticilere, sorumluluk ve iş yükünün yeterli sayıdaki çalışanla ve adil bir şekilde paylaştırılması, işgörenin yeteneğine uygun konumda istihdam edilmesi, işgörenlere iş ile ilgili gerekli eğitim ve bilginin verilmesi, işgörenlerin rahat ve huzurlu bir fiziksel ortamda çalışmalarının sağlanması, işe alım 
süreçlerinde kişilik özelliklerinin göz önünde bulundurulması önerilebilir. Ayrıca, işgörenlere stresle mücadele ve uyum eğitimlerinin verilmesi, iş stresinin azalmasını sağlayabilir.

$\mathrm{Bu}$ çalışma Balıkesir ilindeki kamuya ait sağlık kurumlarında yapılmıştır. Benzer bir çalışma, özel sağlık kurumlarını kapsayacak şekilde yapılabilir. Çalışma sadece sağlık sektörü çalışanlarını kapsadığı için yapılacak araştırmalar diğer sektörlerdeki çalışanları kapsayabilir. Çalışma Balıkesir ilindeki sağlık kurumlarını kapsamaktadır. Farklı illerde ve bölgelerde de araştırmalar yapılabilir. İşgörenlerin performans algıları kendileri tarafından değerlendirilmiştir. Yapılacak araştırmalarda işgörenlerin performansı, yöneticiler ya da çalışma arkadaşları tarafından değerlendirilebilir. Çalışma kapsamında sanal kaytarma ve işgören performansı arasındaki ilişkide iş stresinin düzenleyici etkisi araştırılmıştır. Gelecek çalışmalarda sanal kaytarma ve işgören performansı arasındaki ilişkiyi etkileyen diğer değişkenlerin de incelenmesi önerilebilir.

\section{Kaynakça}

Abualrub, R. F. ve Al-Zaru, I. M. (2008). Job stress, recognition, job performance and intention to stay at work among jordanian hospital nurses. Journal of Nursing Management, 16(3), 227-236.

Afacan Fındıklı, M. (2016). Sanal kaytarma ve iş performansı ilişkisi: Sağlık ve tekstil sektörü çalışanlarının karşılaştırılması. International Journal of Social Inquiry, 9(1), 33-62.

Ajzen, I. (1991). The theory of planned behavior, Organizational Behavior and Human Decision Processes. 50(2), 179-211.

Akar, C. (2018). Işs analitiği.Bursa: Dora Basım-Yayın Dağıtım.

Alkan, M. (2014). Işs stresinin iş performansı üzerine etkisi: SDÜ araştırma ve uygulama hastanesi örneği (Doktora tezi). Süleyman Demirel Üniversitesi, Isparta.

Ampadu, E. O. (2015). Impact of nurse faculty job stress on job satisfaction and intent to remain in academia (Doctoral thesis). Northeastern University, Boston, ABD.

Anandarajan, M.ve Simmers, C. A. (2005) . Developing human capital through personal web use in the workplace: Mapping employee perceptions. Communications of the Association for Information Systems, 15(1), 41.

Askew, K. (2012). The relationship between cyberloafing and task performance and an examination of the theory of planned behavior as a model of cyberloafing (Doctoral thesis). University of South Florida, ABD.

Askew, K., Buckner, J.E., Taing, M.U., Ilie, A., Bauer, J.A. ve Coovert, M.D. (2014). Explaining cyberloafing: The role of the theory of planned behavior. Computers in Human Behavior, 36(1), 510-519.

Aydın, A. (2010). Orman ürünleri sanayi sektöründe toplam kalite yönetimi uygulamalarının çalışan performansı üzerine etkilerinin belirlenmesine yönelik yapısal bir model (Doktora tezi). Karadeniz Teknik Üniversitesi, Trabzon.

Baltaş, Z. (1996). Stres ve sağllk. IX. Ulusal. Psikoloji Kongresi, Boğaziçi Üniversitesi, İstanbul.

Barutçugil, İ. (2002). Performans yönetimi. İstanbul: Kariyer Yayıncılık.

Baumeister, R. F., Muraven, M. ve Tice, D. M. (2000). Ego depletion: A resource model of volition, self-regulation, and controlled processing, social cognition. 18(2), 130-150.

Baysal, A. C. ve Tekarslan, E. (1996). Davranış bilimleri. İstanbul: Avcıol Basım.

Benligiray, S. (2004). İnsan kaynakları yönetimi. Eskişehir: Anadolu Üniversitesi Yayınları. 
Bilgin Demir, İ., Ürek, D., ve Uğurluoğlu, Ö. (2017). Sağlık çalışanlarının sanal kaytarma davranışlarının işte üretkenliklerine etkisi. Online Academic Journal of Information Technology, 8(30): 291-303.

Blanchard, A. L. ve Henle, C. A. (2008). Correlates of different forms of cyberloafing: The role of norms and external locus of control. Computers in Human Behaviour, 24(1), 1067-1084.

Bock G.W. ve Ho, S. L. (2009). Non-work related computing (nwrc). Commun ACM, 52(4), 124-128.

Bogg, J. ve Cooper, C. (1995). Job satisfaction, mental health, and occupational stress among senior civil servants. Human Relations, 48(3), 327-341.

Bulut, F. (2003). Örgütlerde performans değerlendirme ve Erzurum Emniyet Müdürlüğü personeli üzerinde bir çalışma (Yayımlanmamış yüksek lisans tezi). Atatürk Üniversitesi, Erzurum.

Caplan, R. D., Cobb, S. ve French, J. R. (1975). Job demands and worker health; main effects and occupational differences. Washington, D.C.: U.S. Government Printing Office.

Cronbach, L. J. (1951). coefficient alpha and the internal structure of tests. Psychometrika, 16(3), 297-334.

Cüceloğlu, D. (1994). Insan ve davranışı: Psikolojinin temel kavramları. İstanbul: Remzi Kitabevi.

Çarıkçı, İ. H. (2001). Çalışanlarda iş tatminini etkileyen kişisel özellikler ve örgütsel sonuçları: Süpermarket çalışanları üzerinde bir araştırma. Verimlilik Dergisi, 4(1), 161-178.

Çivilidağ, A. (2017). İş yaşamında sanal kaytarmanın iş stresi, iş doyumu ile ilişkisi üzerine bir araştırma. Akademik Bakış Uluslararası Hakemli Sosyal Bilimler Dergisi, 59(1), 55-373.

Çöl, G. (2008). Algılanan güçlendirmenin işgören performansı üzerine etkileri. Doğuş Üniversitesi Dergisi, 9(1), 35-46.

Edwards, J. R. ve Rothbard, N. P. (1999). Work and family stress and well-being: An examination of person-environment fit in the work and family domains. Organizational Behavior And Human Decision Processes, 77(2), 85-129.

Efeoğlu, G. E. (2006). İş-aile yaşam çatışmasının iş stresi, iş doyumu ve örgütsel bağglllı üzerindeki etkileri: İlaç sektöründe bir araştırma (Doktora tezi). Çukurova Üniversitesi, Adana.

Garrett, R. K. ve Danziger, J. N. (2008). Disaffection or expected outcomes: Understanding personal internet use during work. Journal of Computer-Mediated Communication, 13(1), 937-958.

Güleryüz, E. ve Aydın, O. (2006). İş kontrolü ve kontrol isteği ile tükenmişlik ve fiziksel sağlık arasındaki ilişkiler. Türk Psikoloji Dergisi, 21(58), 59.

Gümüştekin, G. E. ve Öztemiz, A. B. (2005). Örgütlerde stresin verimlilik ve performansla etkileşimi. Çukurova Üniversitesi Sosyal Bilimler Enstitüsü Dergisi, 14(1), 271-288.

Gürbüz, S. ve Şahin, F. (2016). Sosyal bilimlerde araştırma yöntemleri, felsefe-yöntem-analiz. Ankara: Seçkin Yayıncılık.

Harrison, R. V. (1978). Person-environment fit and job stress. New York: John Wiley.

Hayes, A. (2013). Introduction to mediation, moderation, and conditional process analysis: A regression-based approach. New York: Guilford Press.

Henle, C. A. ve Blanchard, A. L. (2008). The interaction of work stressors and organizational sanctions on cyberloafing. Journal of Managerial Issues, 20(3), 383-400. 
House, R. J. ve Rizzo, J. R. (1972). Role conflict and ambiguity as critical variables in model of organizational behavior. Organizational Behavior And Human Performance, 7(1), 467-505.

Inzlicht, M. ve Schmeichel, B. J. (2012). What is ego depletion? Toward a mechanistic revision of the resource model of self-control. Perspectives on Psychological Science, 7(1), 450-463.

Karasek Jr, R. A. (1979). Job demands, job decision latitude, and mental strain: Implications for job redesign. Administrative Science Quarterly, 24(2), 285-308.

Kesen, M. ve Sipahi, G. A. (2016). Örgütsel imajın örgütsel bağl1l1k ve işgören performansına etkisi. Journal Of International Social Research, 9(43), 1927-1934.

Kirkman, B. L. ve Rosen, B. (1999). Beyond self-management: Antecedents and consequences of team empowerment. Academy of Management Journal, 42(1), 58-74.

Kıyat, G. B. D., Özgüleş, B. ve Günaydın, S. C. (2018). Algılanan kurumsal itibar ve işe bağl1lığın duygusal emek davranışı üzerine etkisi: Sağlık çalışanları örneği. Hacettepe Sağlık İdaresi Dergisi, 21(3), 473-494.

Koay, K. Y., Soh, P. C. H. ve Chew, K. W. (2017). Do employees' private demands lead to cyberloafing? The mediating role of job stress. Management Research Review, 40(9), 10251038.

Kyriacou, C. (2001). Teacher stress: Directions for future Research. Educational Review, 53(1), 27-35.

Liao, Q., Gurung, A., Luo, X. ve Li, L. (2009). Workplace management and employee misuse: Does punishment matter?. Journal of Computer Information Systems, 50(2), 49-59.

Lim, V.K.G. (2002). The it way of loafing on the job: Cyberloafing, neutralizing and organizational justice. Journal of Organizational Behavior, 23(5), 675-694.

Lim, V. K. G. ve Teo, T. S. H. (2005). Prevalence, perceived seriousness, justification and regulation of cyberloafing in singapore: An exploratory study. Information \& Management, 42(1), 1081-1093.

Mahatanankoon, P., Anandarajan, M. ve Igbaria, M. (2004). Development of a measure of personal web usage in the workplace. Cyberpsychology \& Behaviour. 7(1), 93-104.

Muse, L. A., Harris, S. G. ve Feild, H. S. (2003). Has the inverted-u theory of stress and job performance had a fair test?. Human Performance, 16(4), 349-364.

Nart, S., ve Yıldırım, Y. T. (2018). Current debates in management \& organization. London: IJOPEC Publication.

Nunnally, J. C. (1978). Psychometric theory. New York: McGraw-Hill.

Oravec, J. A. (2002). Constructive approaches to internet recreation in the workplace. Communications of the ACM, 45(1), 60-63.

Oxford Dictionary, (2018). https://en.oxforddictionaries.com/definition/distress (Erişim tarihi: 28.09.2018).

Öğüt, A., Akgemci, T. ve Demirsel, M.T. (2004). Stratejik insan kaynakları yönetimi bağlamında örgütlerde işgören motivasyonu süreci. Selçuk Üniversitesi Sosyal Bilimler Enstitüsü Dergisi, 12(1), 245-258.

Örücü, E. ve Özüdoğru, M. (2018). Örgütsel güven ile sanal kaytarma davranışları arasındaki ilişkinin belirlenmesine yönelik bir çalışma. Adnan Menderes Üniversitesi Sosyal Bilimler Enstitüsü Dergisi, 5(3), 66-80.

Patel, C. (1989). Stres management. London: Vermilion Pres. 
Prasad, S., Lim, V.K. ve Chen, D.J. (2010). Self-regulation, individual characteristics and cyberloafing. Taipei: PACIS 2010 Proceedings.

Rousseau, D. M. ve Mclean Parks, J. (1993). The contracts of individuals and organizations. Research in Organizational Behavior, 15(1), 1-43.

Sabuncuoğlu, Z. ve Tüz, M. (2001). Örgütsel psikoloji. Bursa: Ezgi Kitabevi.

Sağlık Bakanlığı, Sağllk araştırmaları genel müdürlüğü, https://www.saglik.gov.tr/TR,30485/saglik-istatistikleri-yilligi-2016 (Erişim tarihi: 15.09.2018).

Sakallı, S. Ö. (2015). Örgütsel adalet ile örgütsel güven ilişkisinde kişilik özelliklerinin düzenleyici rolü ve bir alan araştırması (Doktora tezi). Balıkesir Üniversitesi, Balıkesir.

Santos, A. S. T. (2016). Impact of cyberloafing and physical exercise on performance: An experimental research (Doctoral thesis). Lizbon Üniversitesi, Portekiz.

Seyle, H. (1974). Stress without distress. School Guidance Worker, 32(5), 5-13.

Shahıd, M. N., Latif, K., Sohail, N. ve Ashraf, M.A. (2011). Work stress and employee performance in banking sector evidence from district faisalabad, Pakistan. Asian Journal of Business and Management Sciences, 1(7), 38-47.

Sheikh, A., Atashgah, M. S. ve Adibzadegan, M. (2015). The antecedents of cyberloafing: A case study in an iranian copper industry. Computers in Human Behavior,51(1), 172-179.

Şahin, N. H. ve Batıgün, A. D. (1997). Bir özel hastahane sağlık personelinde iş doyumu ve stres. Türk Psikoloji Dergisi, 1(9), 57-73.

Şen, E., Tozlu, E., Ateşoğlu, H. ve Özdemir, A. (2016). The effects of work stress on cyberloafing behavior in higher education institutions. Social Sciences, 1(1), 523-535.

Şimşek, M.Ş., Akgemci, T. ve Çelik, A. (2008). Davranış bilimlerine giriş ve örgütlerde davranış. Ankara: Gazi Kitabevi.

Spector, P. E., Fox, S., Penney, L. M., Bruursema, K., Goh, A., ve Kessler, S. (2006). The dimensionality of counterproductivity: Are all counterproductive behaviors created equal?. Journal Of Vocational Behavior, 68(3), 446-460.

Tabachnick, B.G. ve Fidell, L.S. (2001). Using multivariate statistics. Boston: Allyn and Bacon.

Taneja, A., Fiore, V. ve Fischer, B. (2015). Cyber-slacking in the classroom: Potential for digital distraction in the new age. Computers \& Education, 82(1), 141-151.

Tekingündüz, S., Kurtuldu, A. ve Eğilmez, Ç. (2016). Sosyal destek, işe yabancılaşma ve iş stresinin iş gören performans1 üzerindeki etkisinin incelenmesi. International Journal of Human Sciences, 13(1), 683 - 694.

Turunç, Ö. (2010). Organizasyonlarda kontrol algılamalarının örgütsel özdeşleşme ve iş performansına etkisi. C.Ü. Íktisadi ve İdari Bilimler Dergisi, 11(1), 251-269.

Türkiye İstatistik Kurumu (TÜIK) (2018a). Girişimlerde bilişim teknolojileri kullanım araştırması. TÜIK haber bülteni, Sayı: 27820, ss.1.

Türkiye İstatistik Kurumu (TÜIK) (2018b). Hanelerde bilişim teknolojileri kullanımı. http://www.tuik.gov.tr/PreTablo.do?alt_id=1028 (Erişim tarihi: 12.09.2018).

Üçüncü, K., Akyüz, İ., Aydın, A. ve Taşdemir, T. (2008). Stres kaynaklarının ve diğer bazı faktörlerin akademik performans üzerine etkilerinin incelenmesi ve performansin geliştirilmesi. KTÜ Bilimsel Araştırma Projeleri Birimi Sonuç Raporu, Trabzon. 
Vitak, J., Julia C. ve Robert L. (2011). Personal internet use at work: Understanding cyberslacking, computers in human behavior, 27(1), 1751-1759.

Wagner, D. T., Barnes, C.M., Lim, V.K.G. ve Ferris, D.L. (2012). Lost sleep and cyberloafing: Evidence from the laboratory and a daylight saving time quasiexperiment. Journal of Applied Psychology, 97(1), 1068-1076.

Zafar, Q., Ali, A., Hameed, T., İlyas, T. ve Younas, H. (2015). The influence of job stress on employees performance in Pakistan. American Journal of Social Science Research, 1(4), 221-225.

\section{ETIKK ve BİLIMSEL İLKELER SORUMLULUK BEYANI}

$\mathrm{Bu}$ çalışmanın tüm hazırlanma süreçlerinde etik kurallara ve bilimsel atıf gösterme ilkelerine riayet edildiğini yazar(lar) beyan eder. Aksi bir durumun tespiti halinde Afyon Kocatepe Üniversitesi Sosyal Bilimler Dergisi'nin hiçbir sorumluluğu olmayıp, tüm sorumluluk makale yazarlarına aittir. 